\title{
الإيقاع السمهي والبصري في القصة الشاعرة
}

\author{
اعضالخ

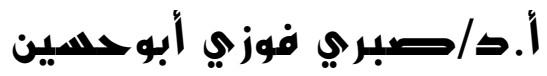

أستاذ الأدب والنقد بكلية اللغة العربية بالزقازيق - جامعة الأزهر

Doi: 10.12816/mdad.2019.48353

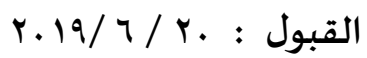

r.19/0/ : اسستلام

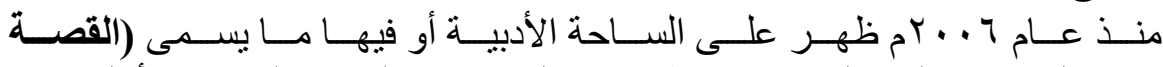

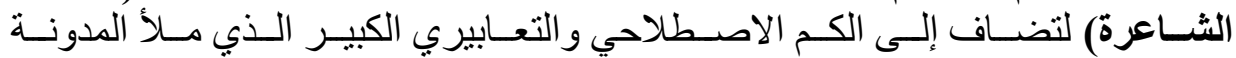

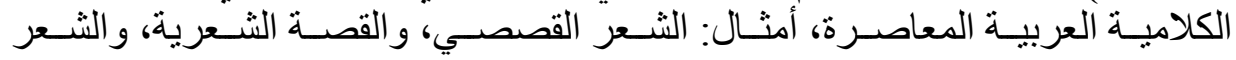

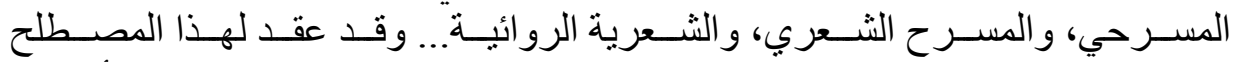

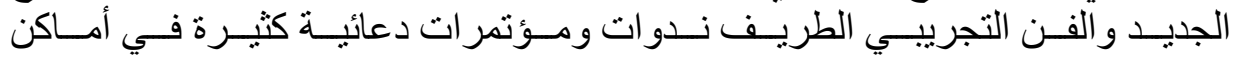

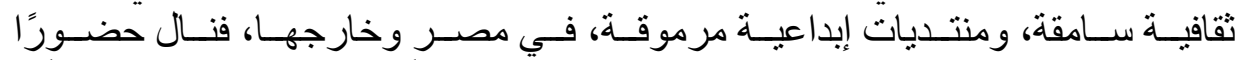

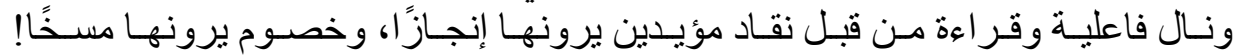

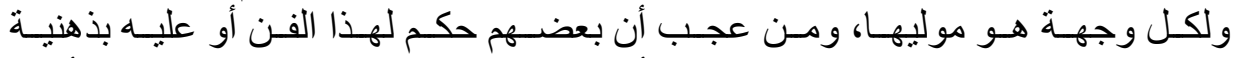

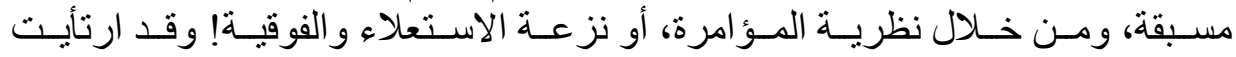

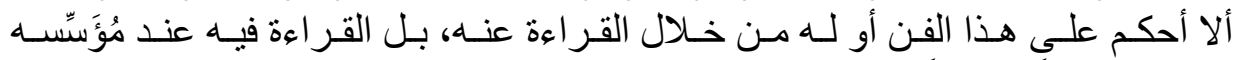

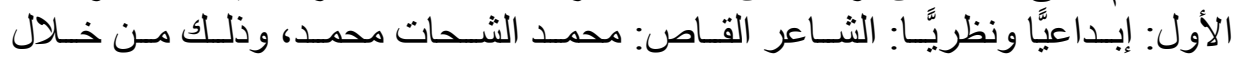

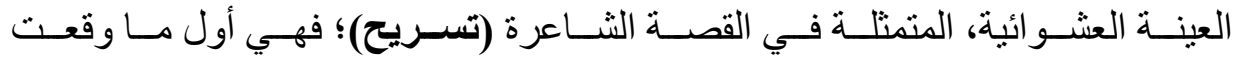

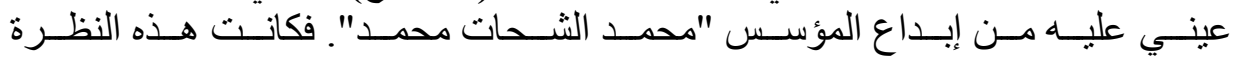
التدبرية الأولى لهذا الفن، من خلال البنية الثعرية الأساسية فيه، وهي الإيقاع.

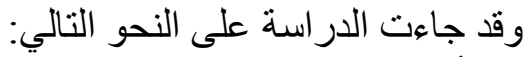

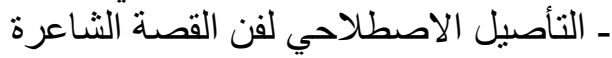

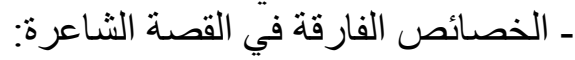

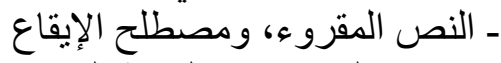

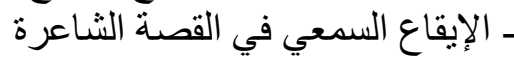

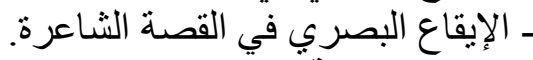

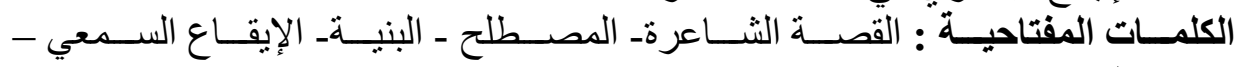
الإيقاع البصري 


\section{Abstarct:}

Since $Y . .7$, he appeared on the literary scene or the so-called (Alkesa Alsha'era) to add to the great idiomatic and expressive quantity that filled the modern Arabic verbal blog, such as: fiction, poetry, theatrical poetry, theater poetry, fiction poetry ... This new term and experimental art has held many symposia and propaganda conferences in prestigious cultural places, and prestigious creative forums, in Egypt and abroad, and received attendance and effectiveness and read by many diverse supporters critics see it as an achievement, and opponents see it terrible! Each destination is Molly, and people love doctrines! It is a wonder that some of them ruled for this art or a prior mind, and through conspiracy theory, or the tendency of superiority and sick meta!

I have decided not to judge this art or him by reading about it, but reading it in the first founder: creative and theoretical: the poet reciting: Mohammed Shahat Mohammed, and through a random sample, represented by Alkesa Alsha'era (tsryh); What signed my eyes on the creativity of the founder. This was the first management view of this art, through the basic poetic structure in it, namely rhythm. The Soul

The study was as follows:

-Idiomatic rooting of the art of the poet

-Distinguishing characteristics of the poet:

-Read text, and the term rhythm

-The auditory rhythm in the poet's story

-Visual rhythm in the poet's story. The Soul

The detail will come in that.

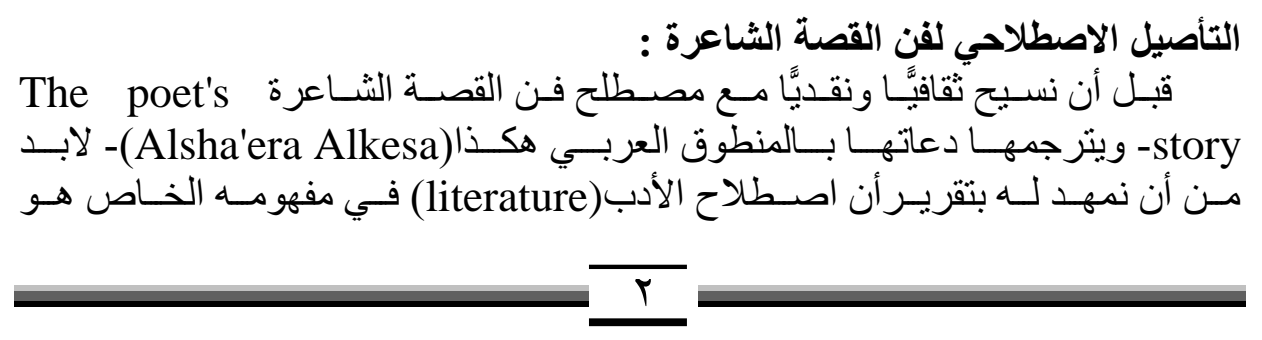




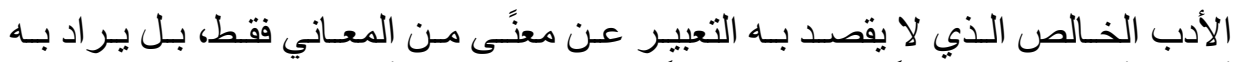

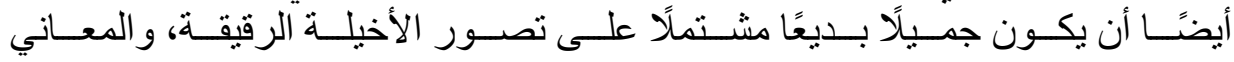

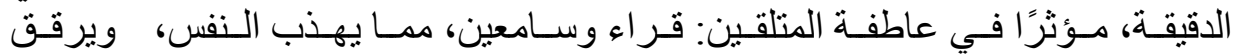

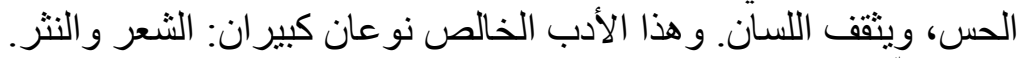

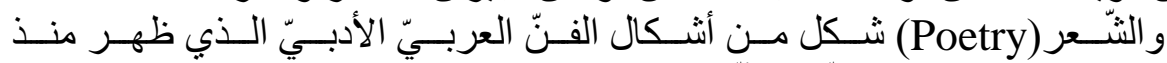

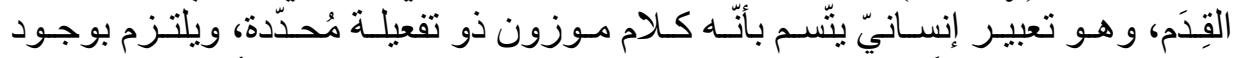

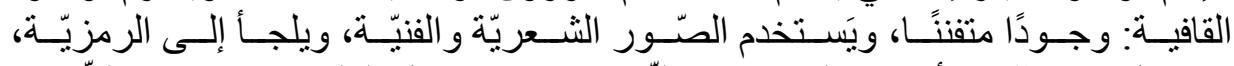

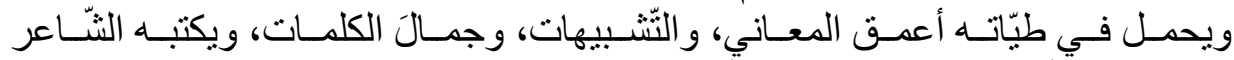

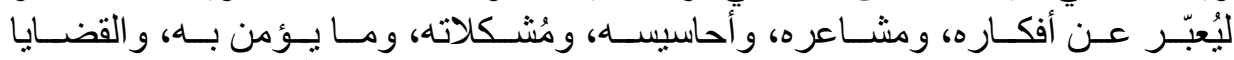

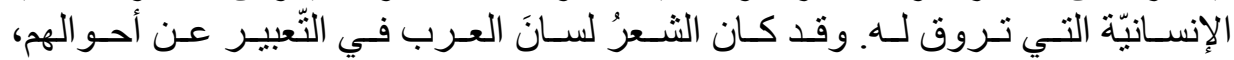

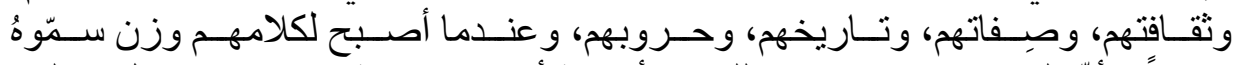

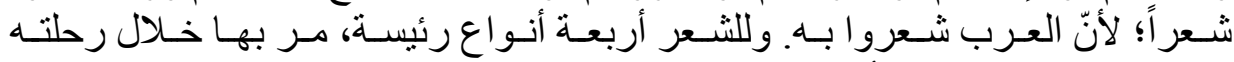

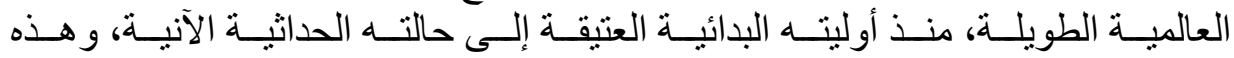

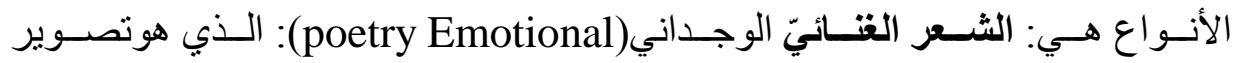

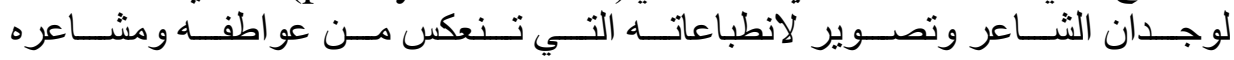

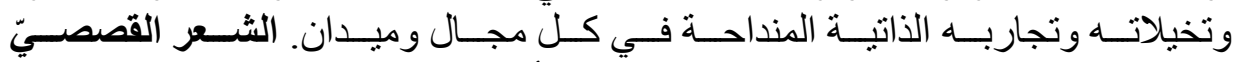
(poetry Fiction)

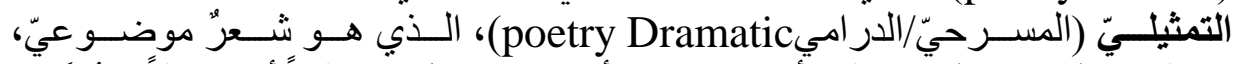

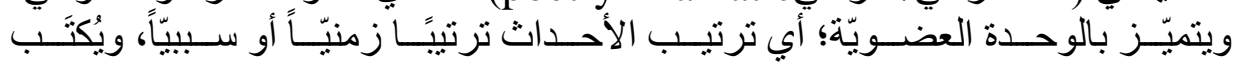

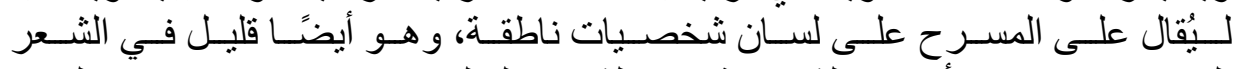

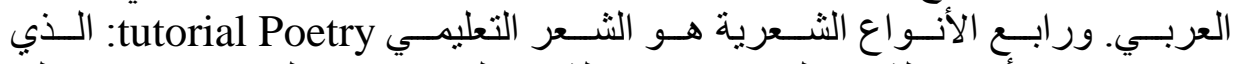

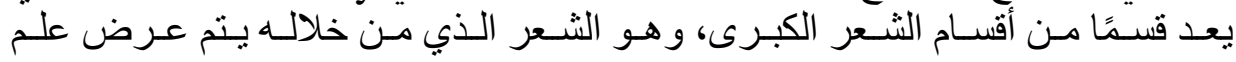

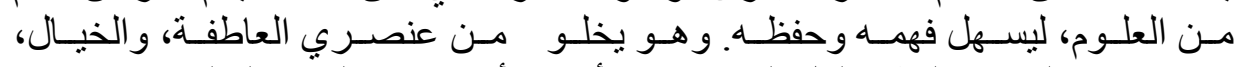

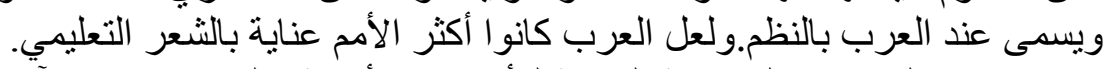

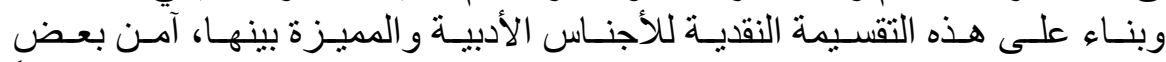

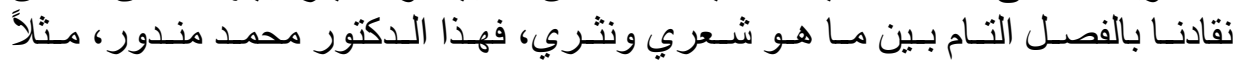

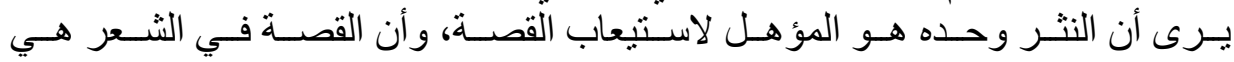

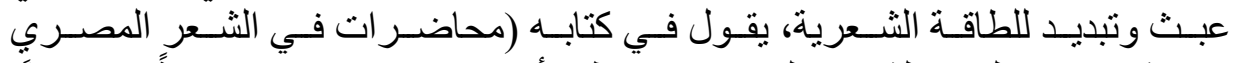

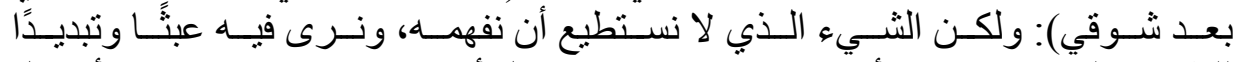

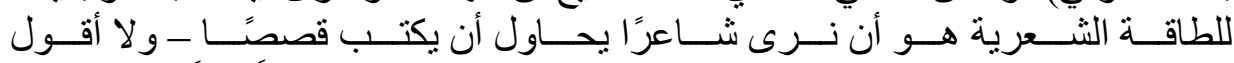

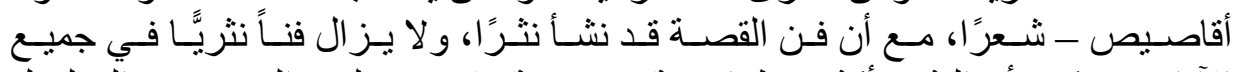

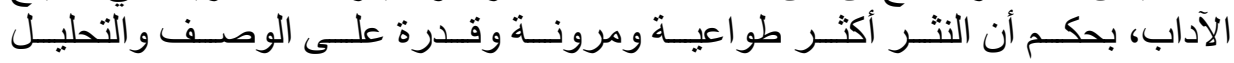




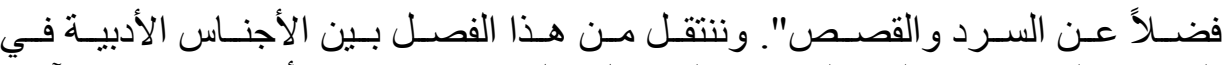

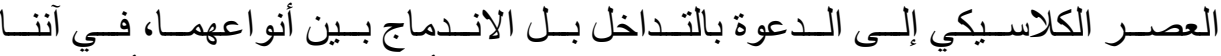

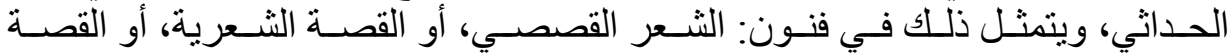

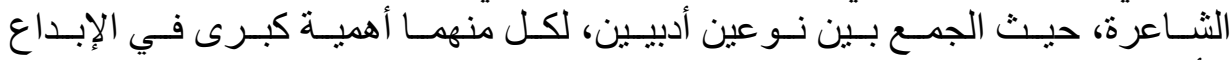

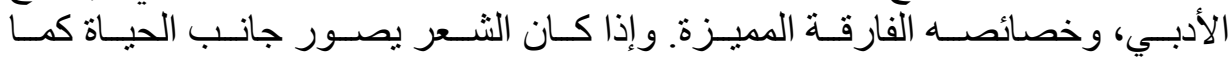

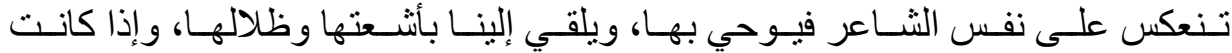

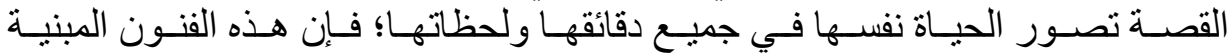

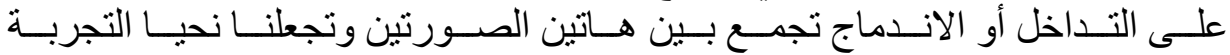

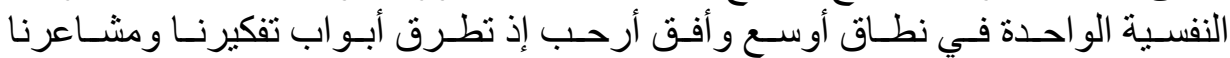

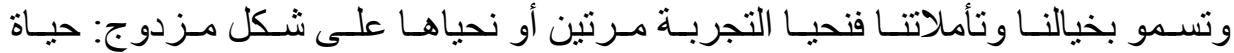

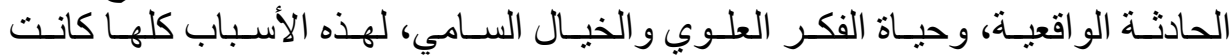

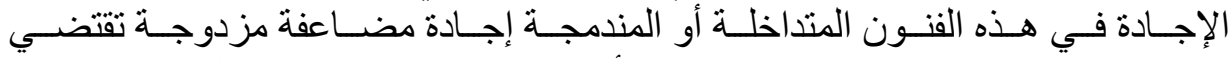

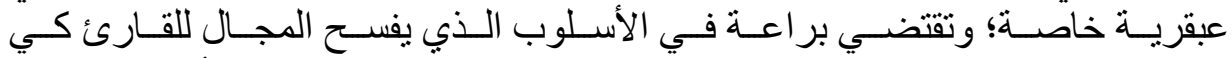

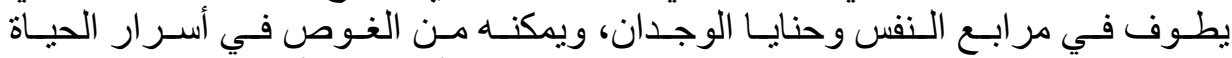

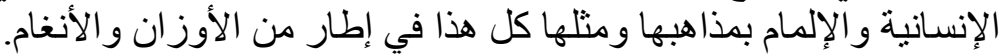

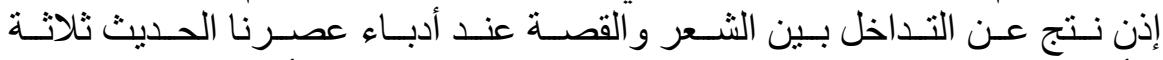

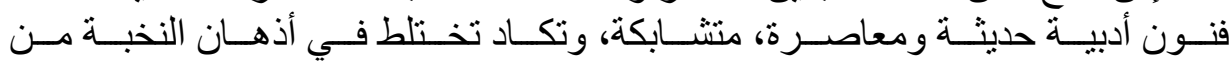

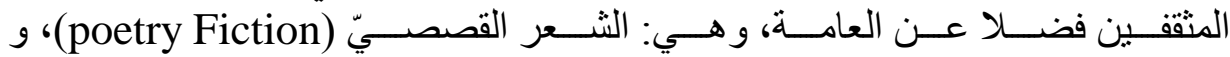

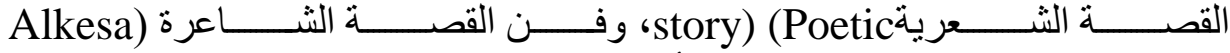
Alsha'era

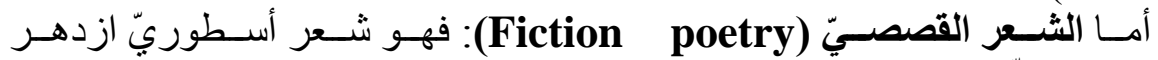

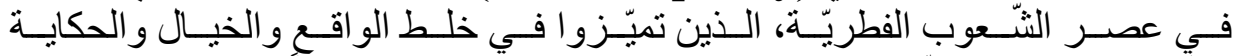

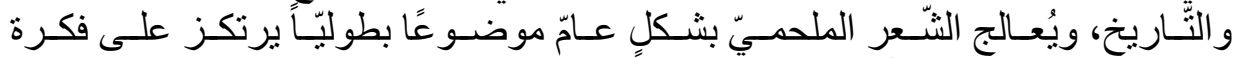

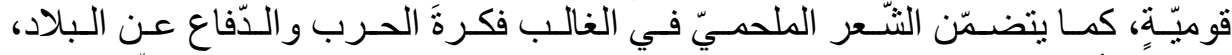

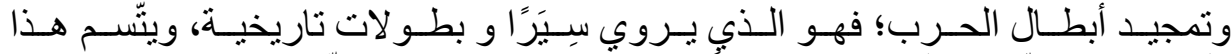

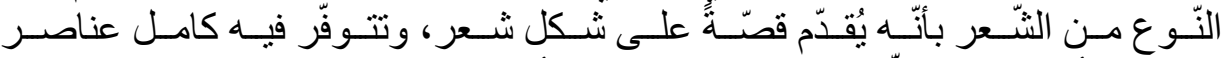

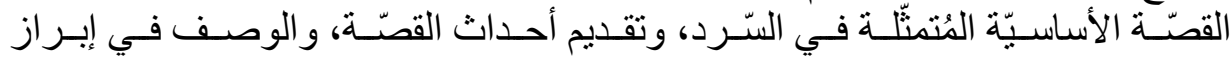

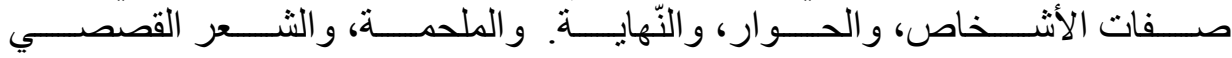

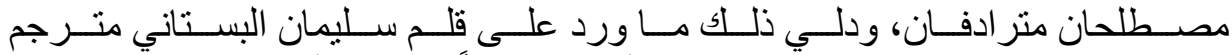

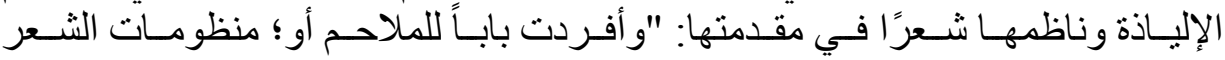

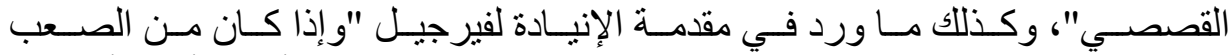

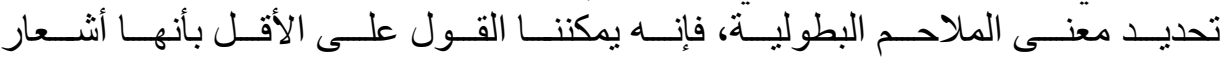




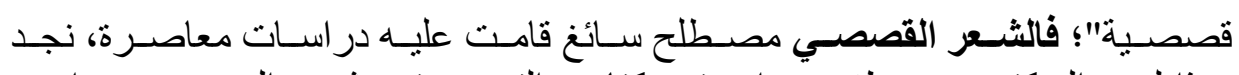

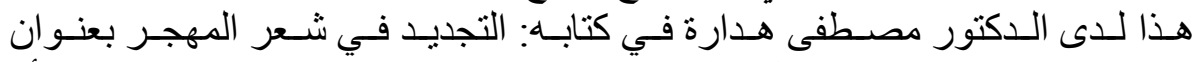

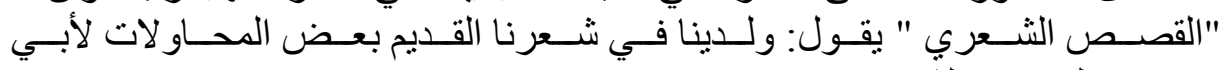

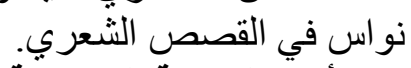

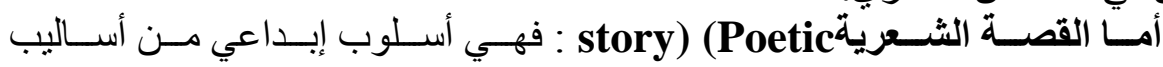

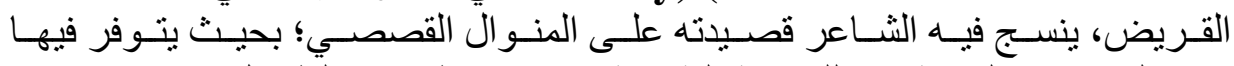

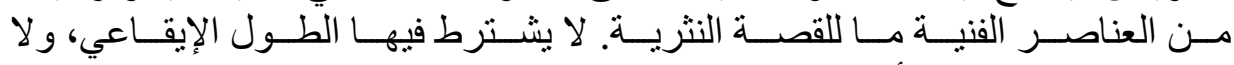

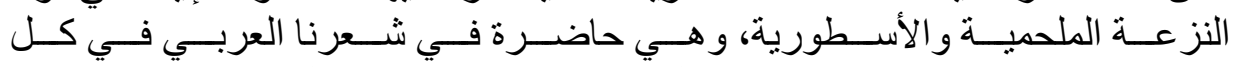

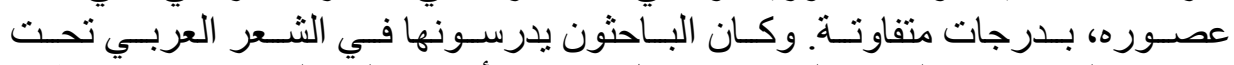

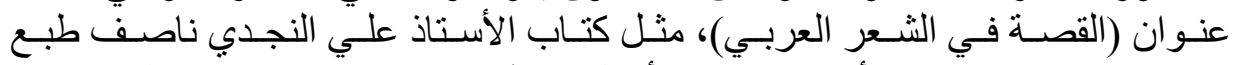

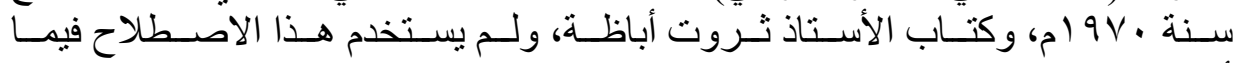

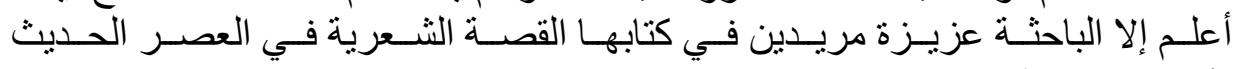

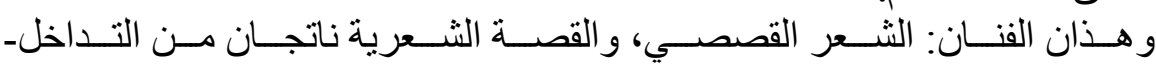

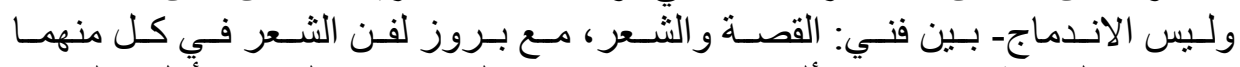

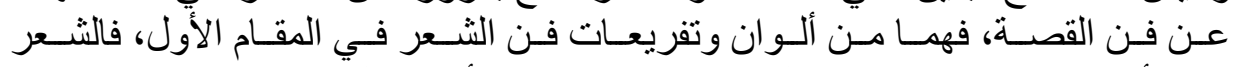

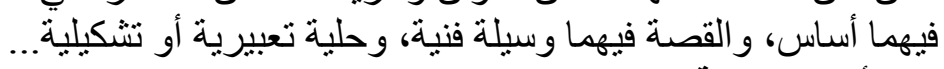

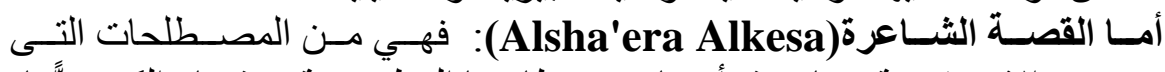

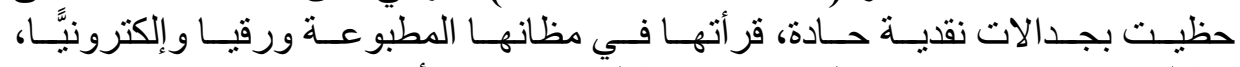

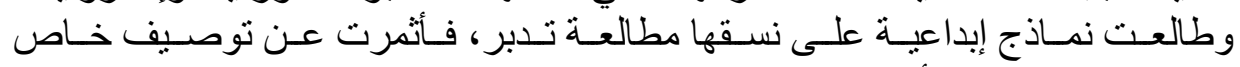
بها، بمكننا إيجازه في أن: إعند

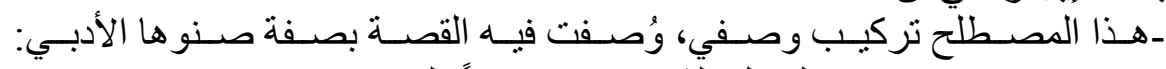

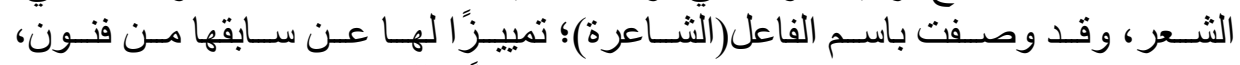

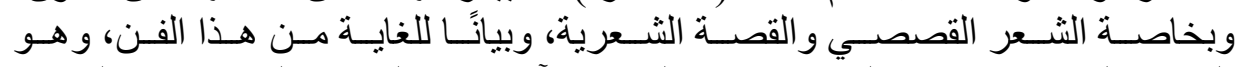

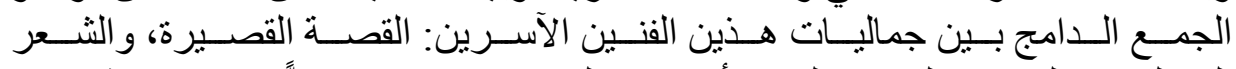

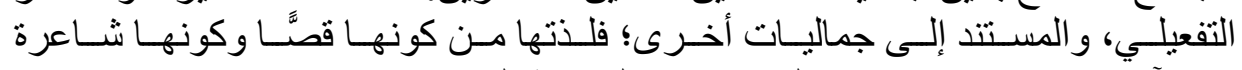

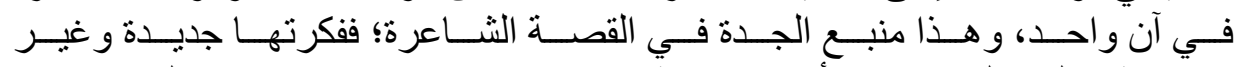

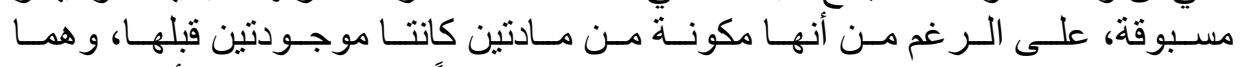

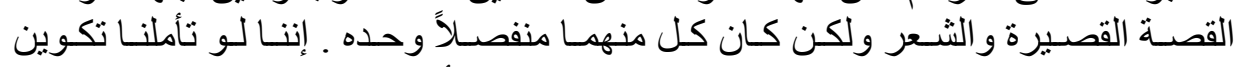

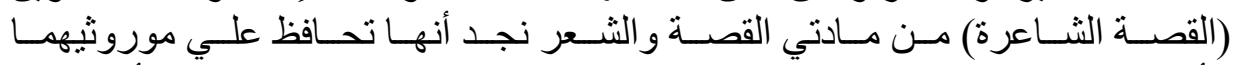

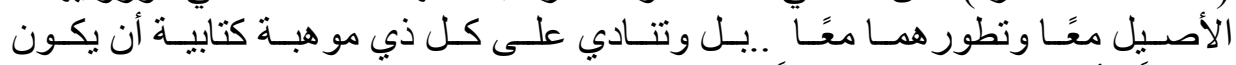

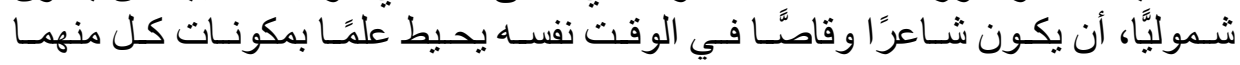




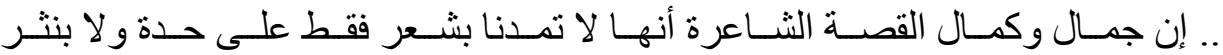

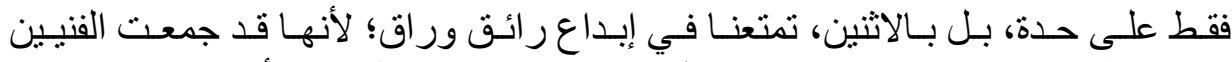

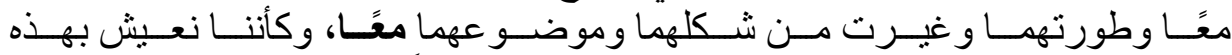

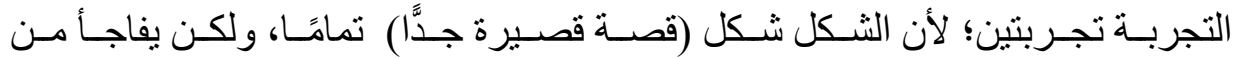

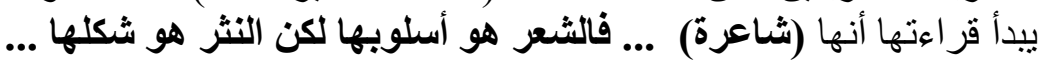

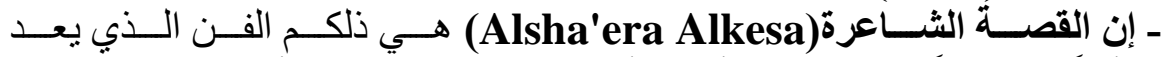

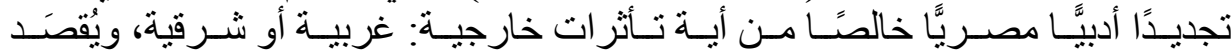

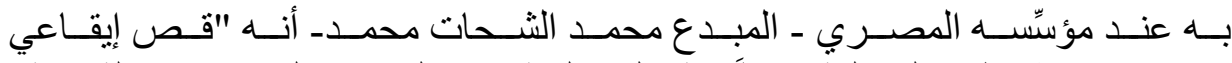

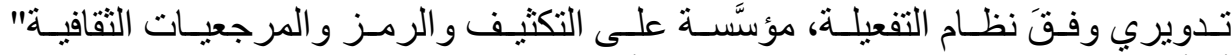

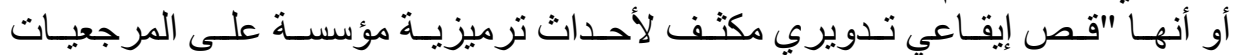

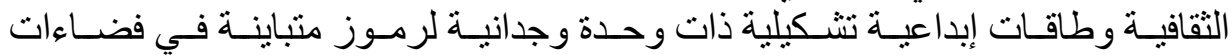

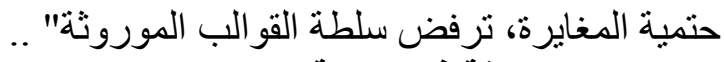

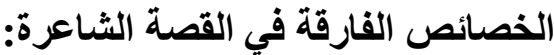

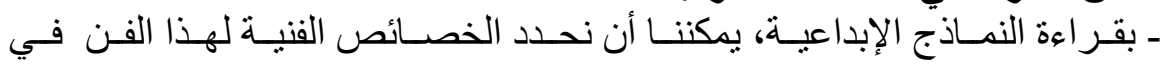

\section{- ت القَصْدية الإبداعية}

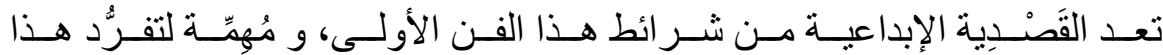

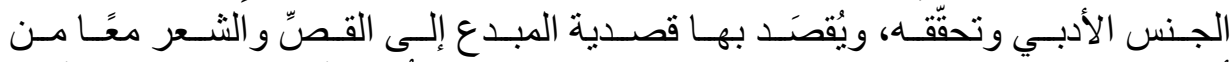

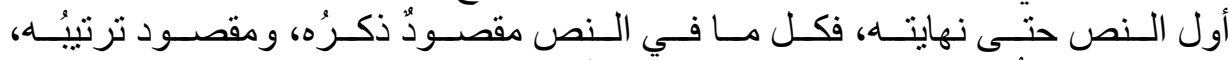

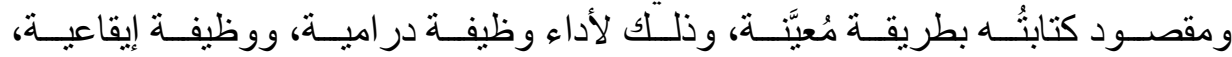

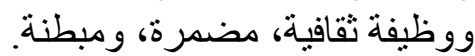

- - درامية النص:

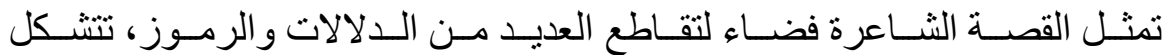

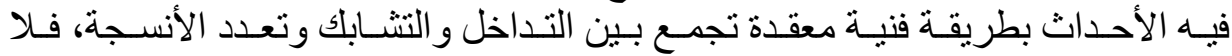

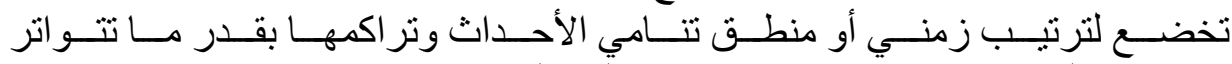

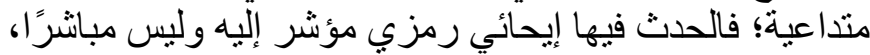

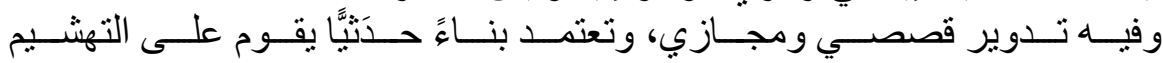

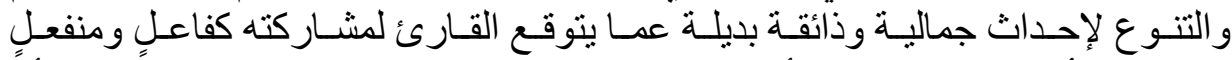

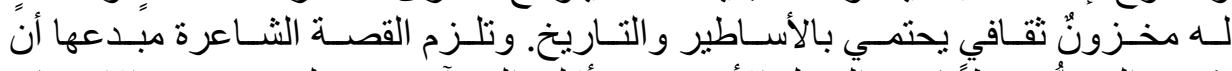

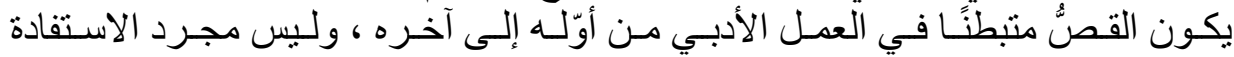

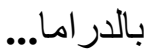




\section{-}

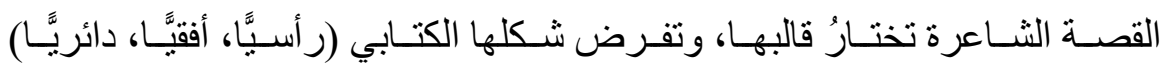

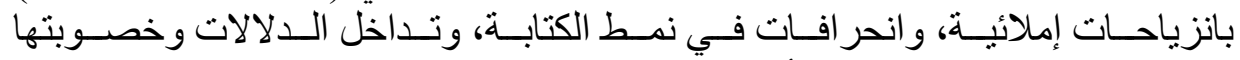

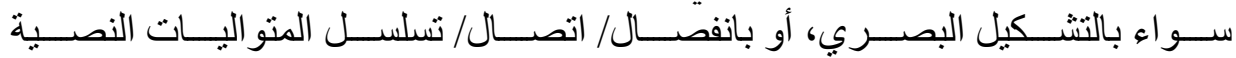

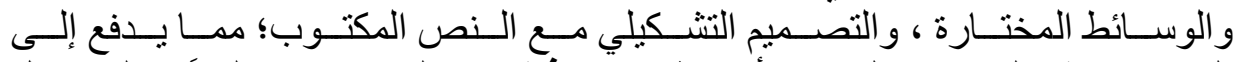

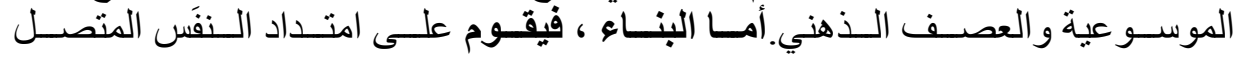

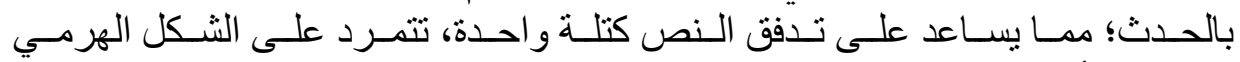

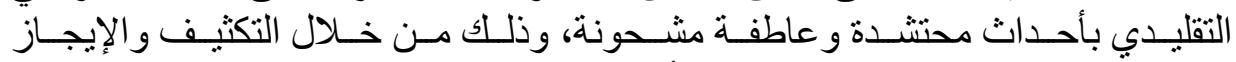

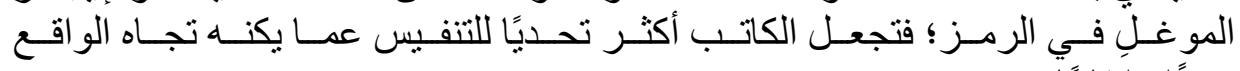
رمزًا و إيقاعًا.

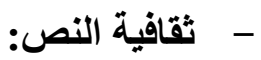

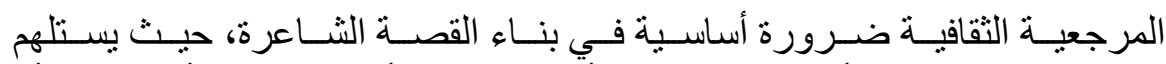

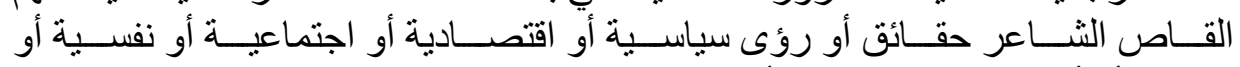

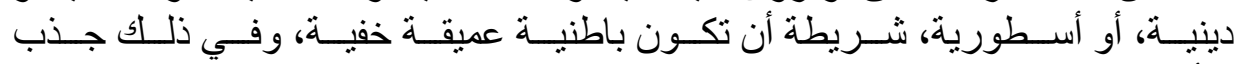
وتأثير ....

\section{- تفعيلية النص: - تصنية}

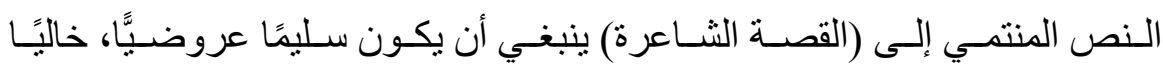

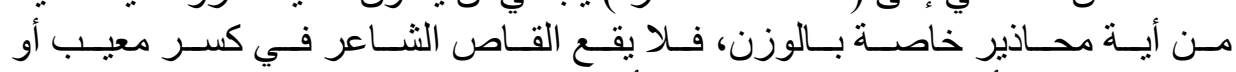

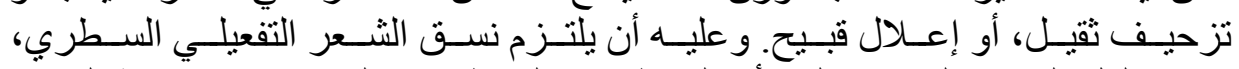

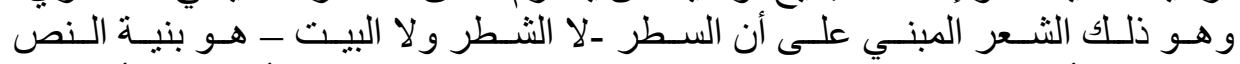

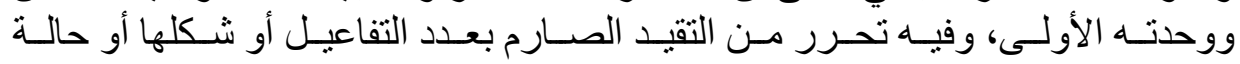

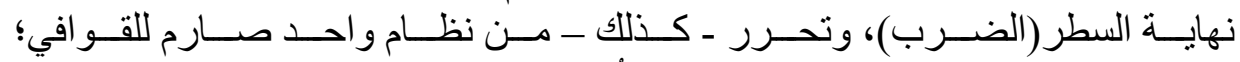

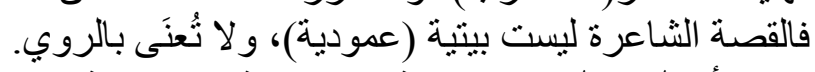

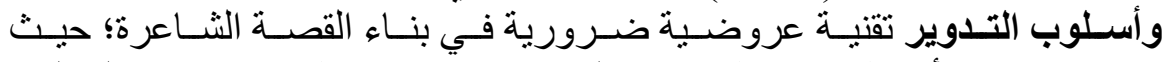

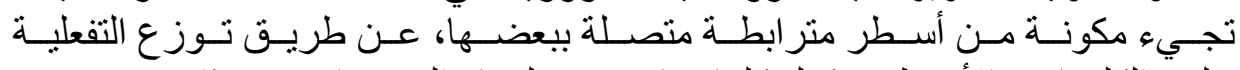

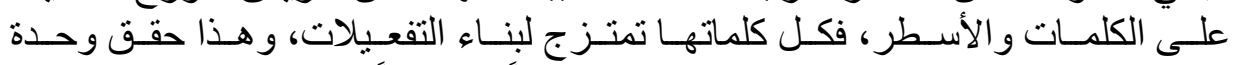

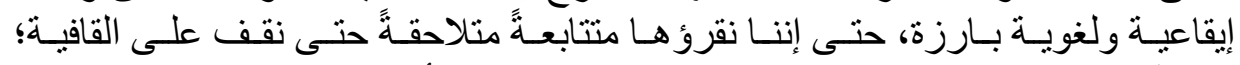

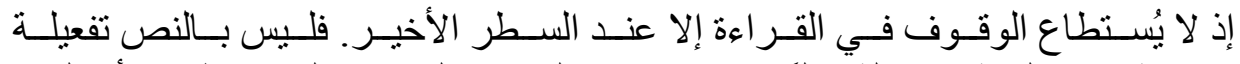

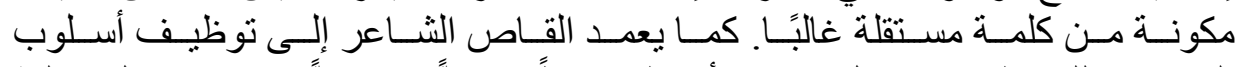

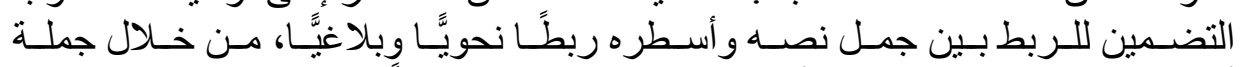

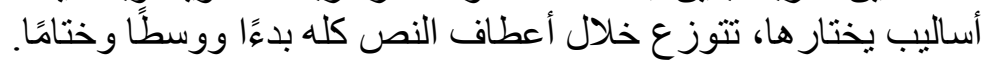

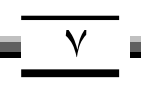




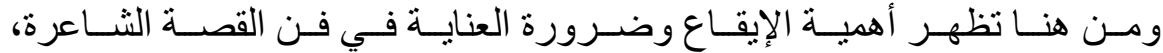

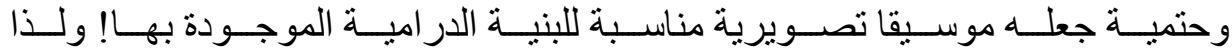

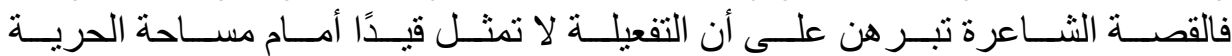

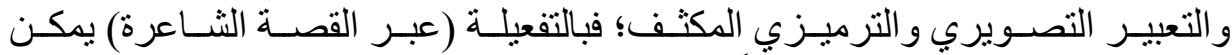

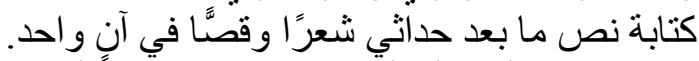

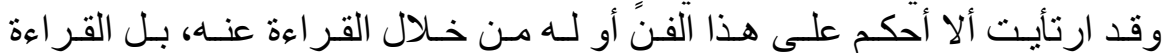

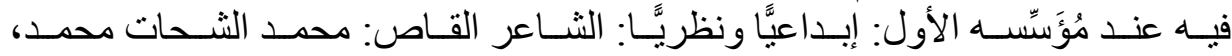

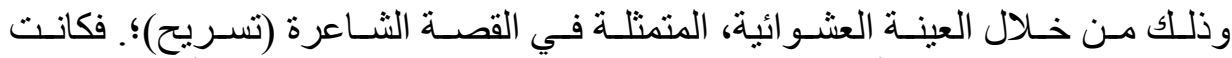

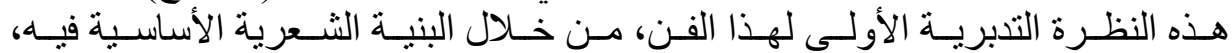

النص المقروء إيقاعيَّا

$$
\text { و هي الإيقاع. - مذاع. }
$$

تسريح

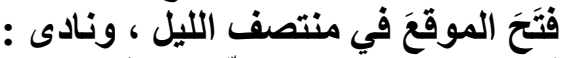

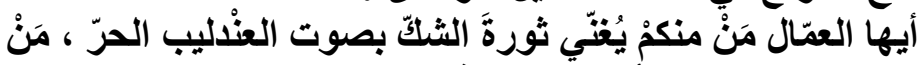

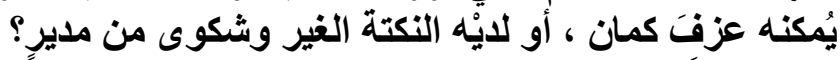

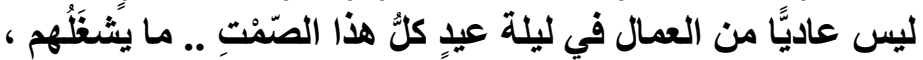

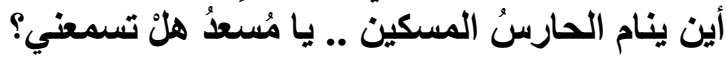
ردّتَّْ ثريّا: ومتى تفهم أنّ الكهرباء انقطعتُّ مُنذ خروج الليثِ في نشرة أصحاب

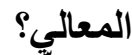

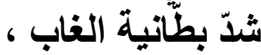

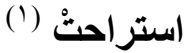
ثانيًا: مصطلح احت الإيقاع: (1)

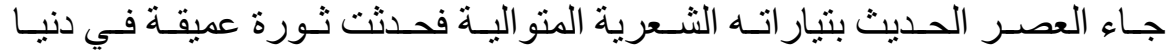

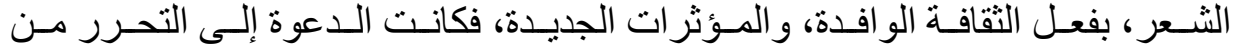

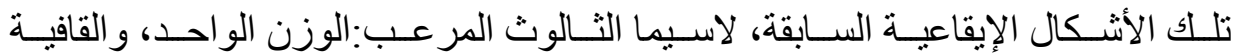

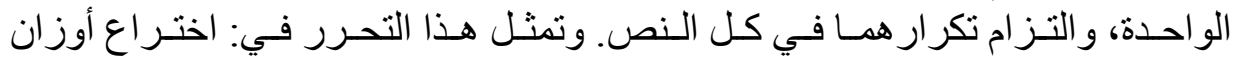

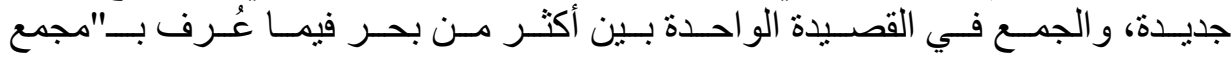

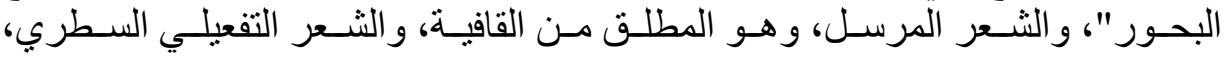

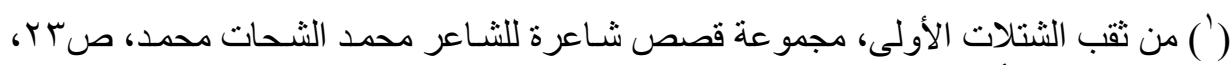

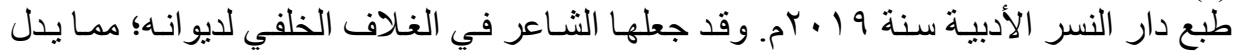




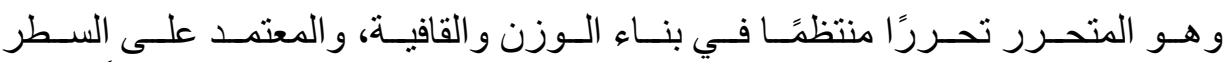

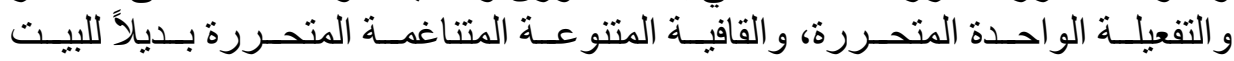

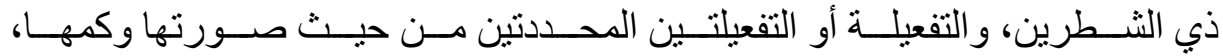

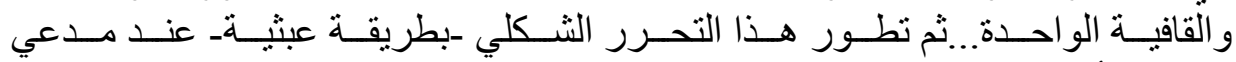

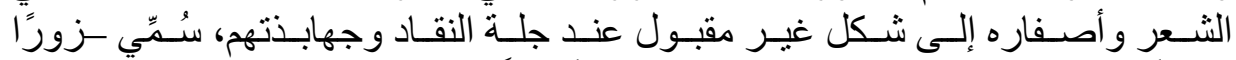

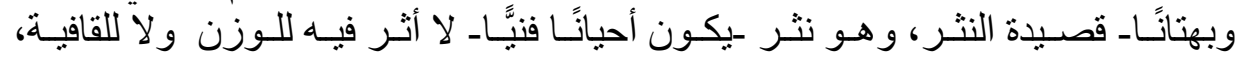

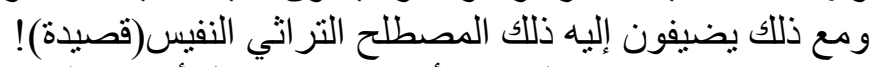

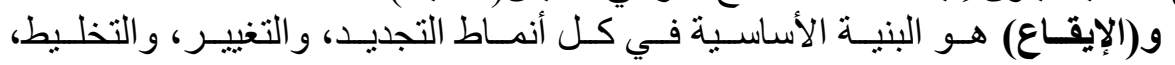

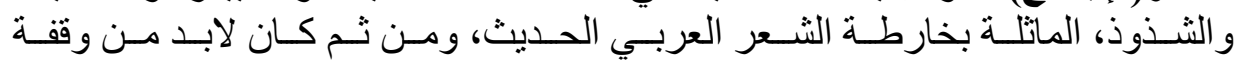
لغوية واصطلاحية معه على النحو التالي:

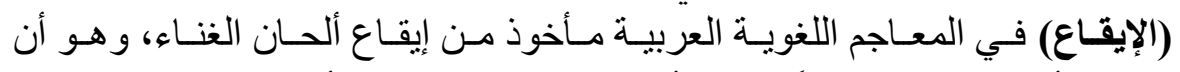

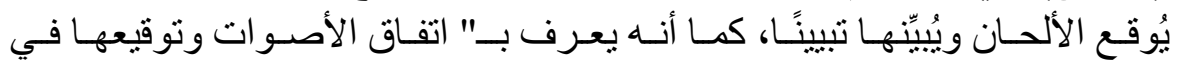

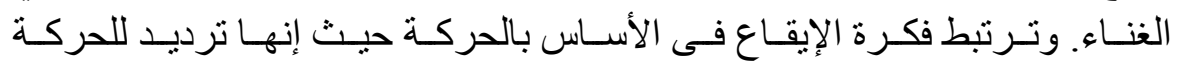

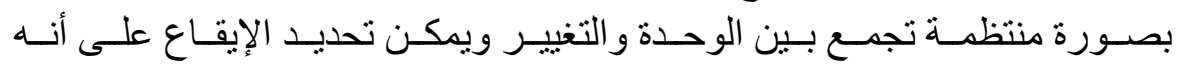
تكر ار لعنصر ما.... (ب)

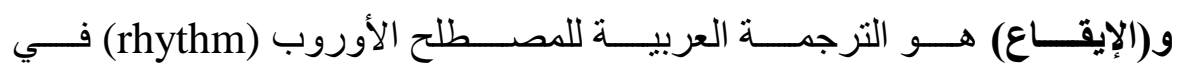

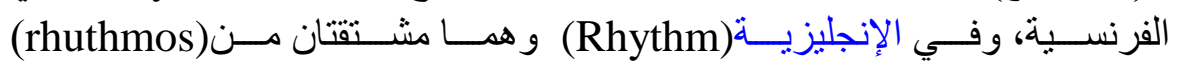

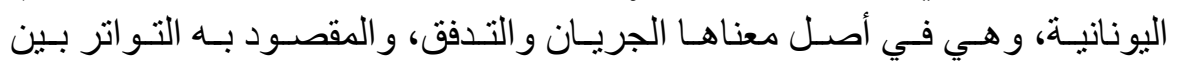

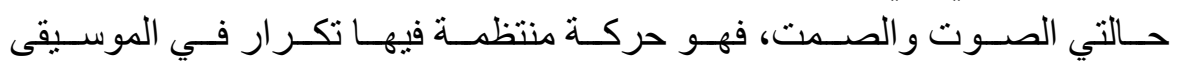

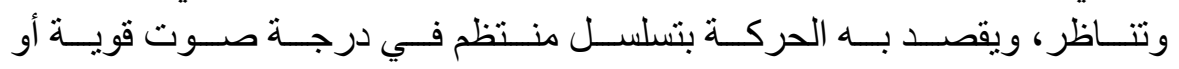
ضنعيفة.

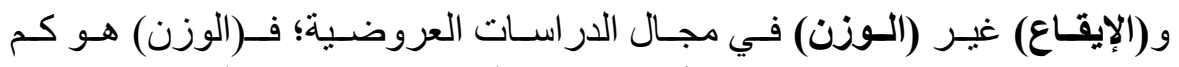

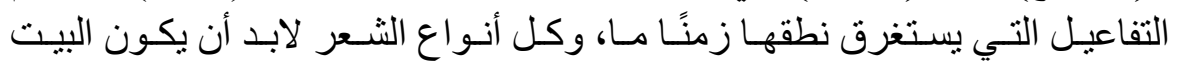

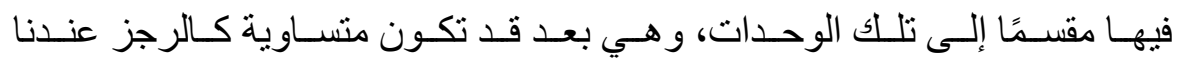

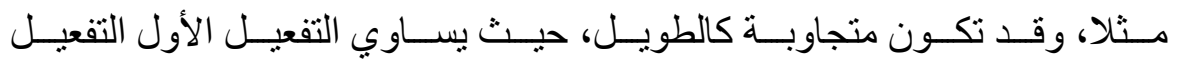

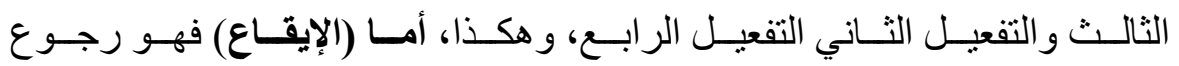

(') راجع معجم لسان العرب، ومعجم القاموس المحيط، و المعجم الوسبط، ومعجم اللغـة العربية 9

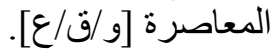




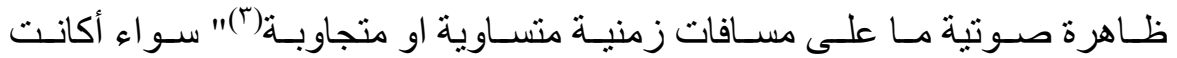

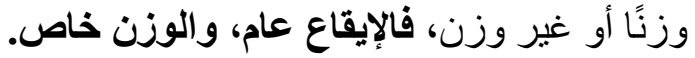

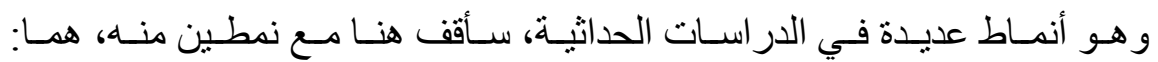

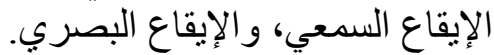
الإيقاع السمعي في القصة الإعة الثماعرة:

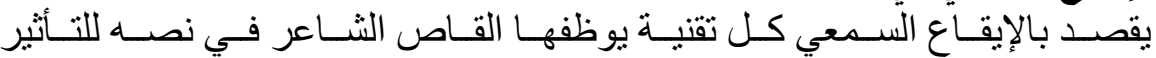

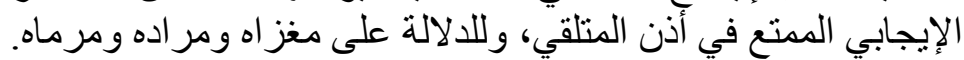
وهو يتمثل في القصة الثناعرة المبحوثنة(تسريح) في: 1- التفعيل

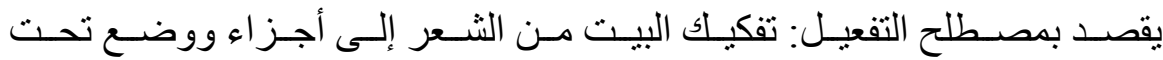

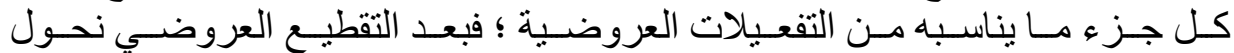

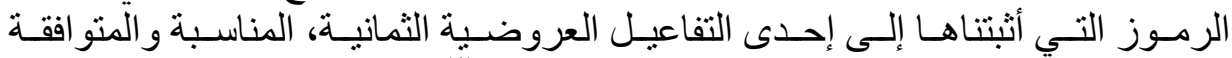

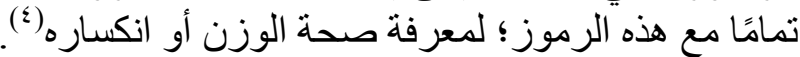

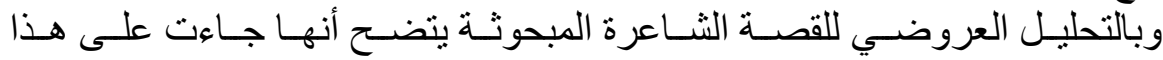

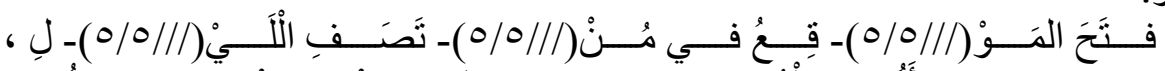

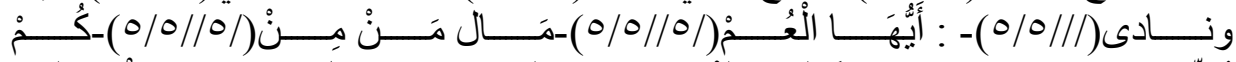

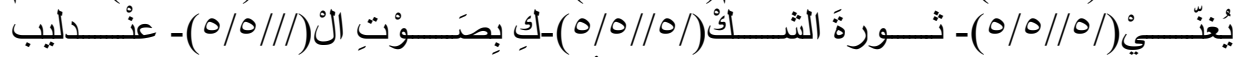

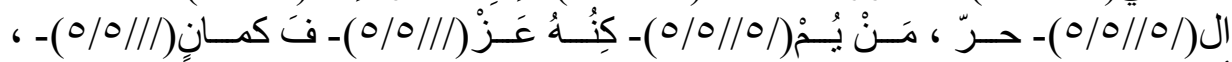

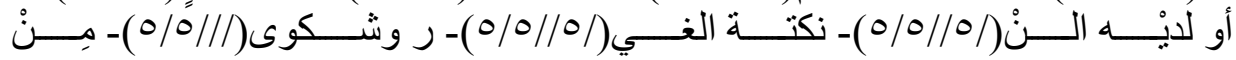

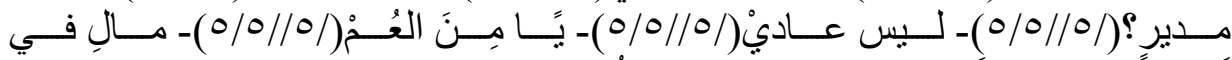

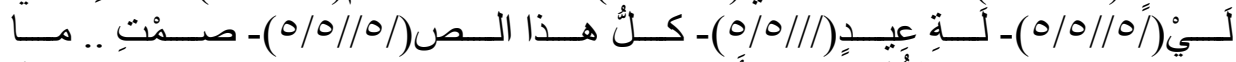

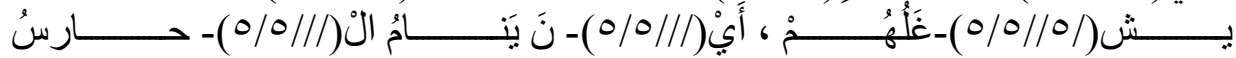

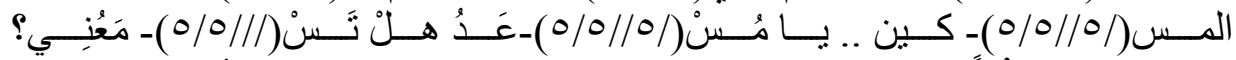

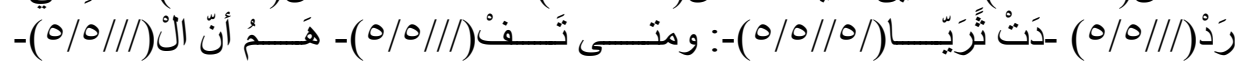

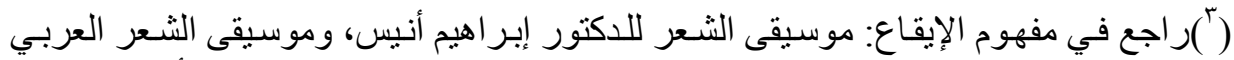

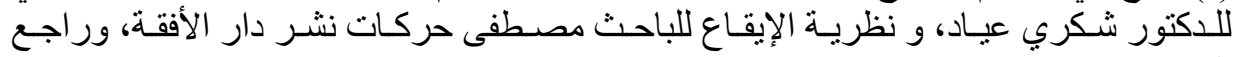

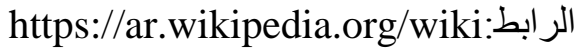

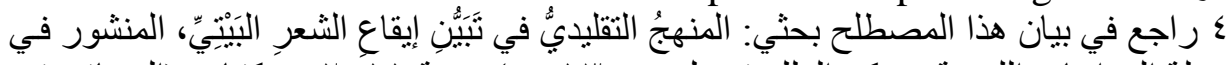

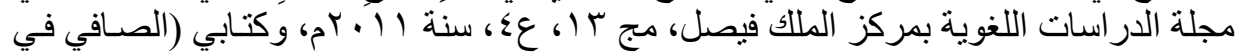

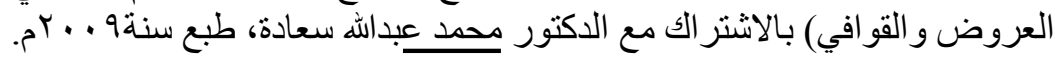




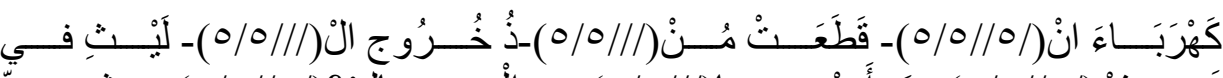

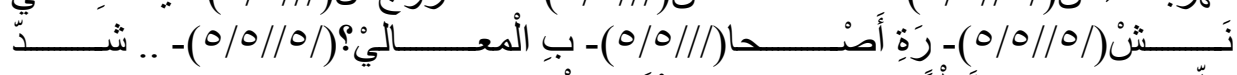

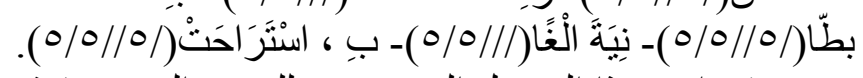

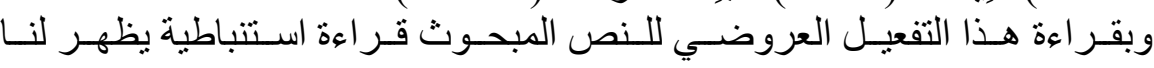

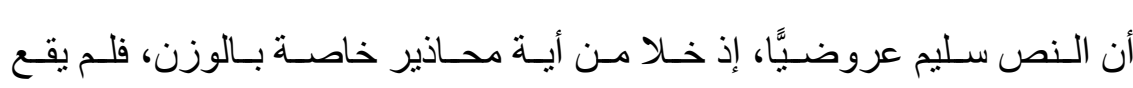
الآتي: - n

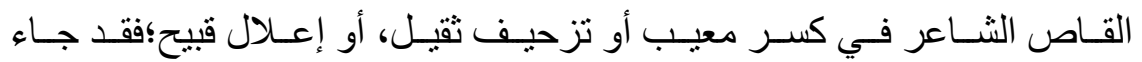

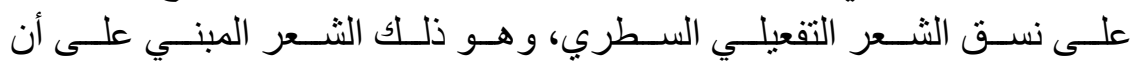

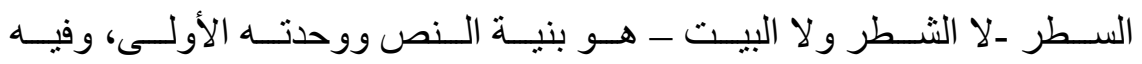

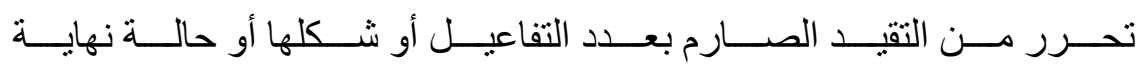

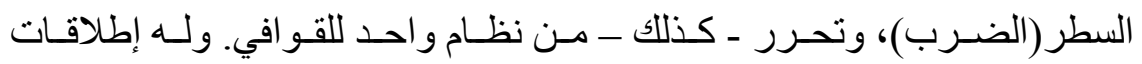

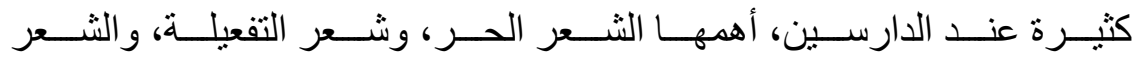

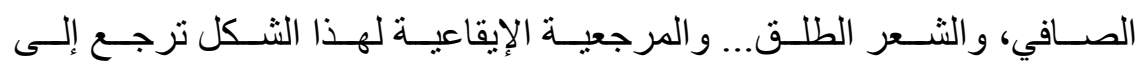

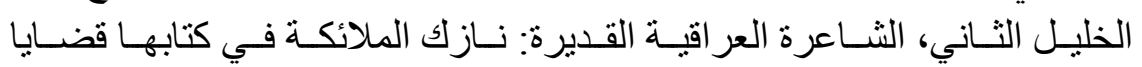
الشعر العربي المعاصر ().....

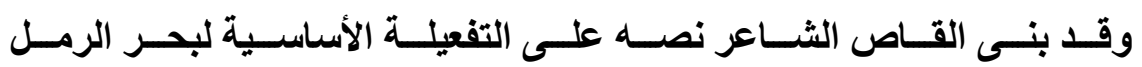

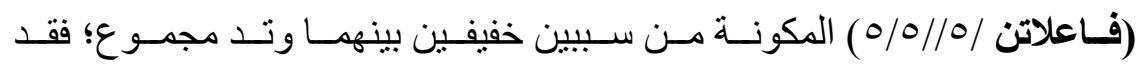

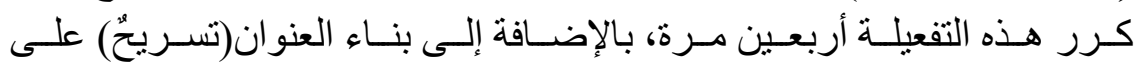

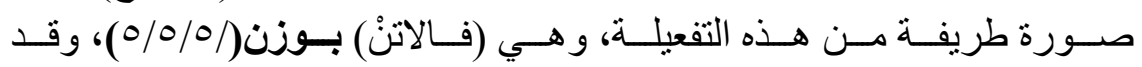

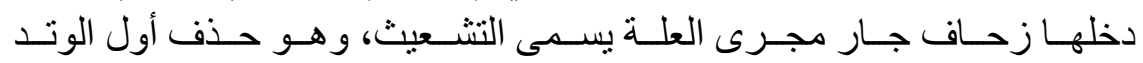

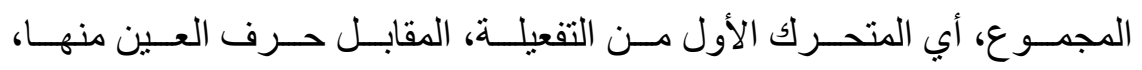

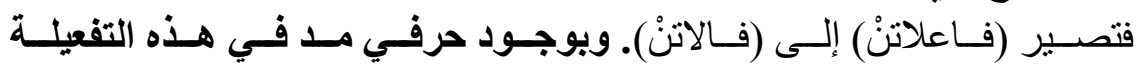

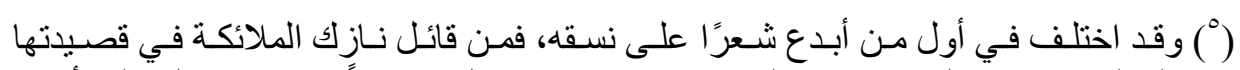

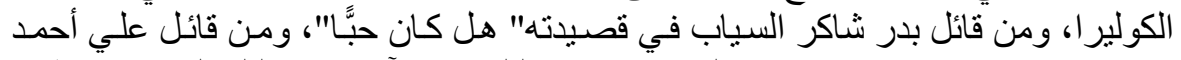

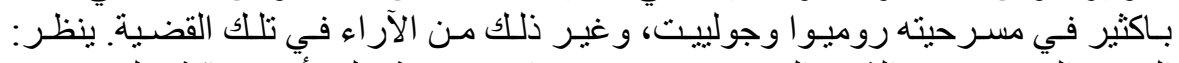

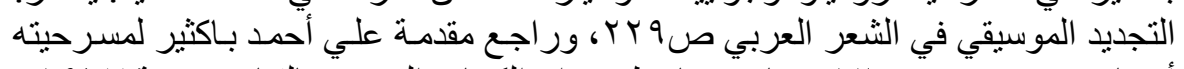

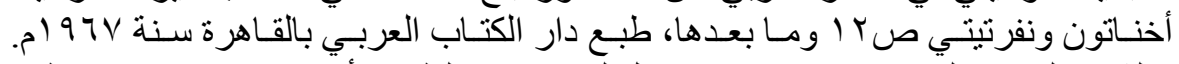

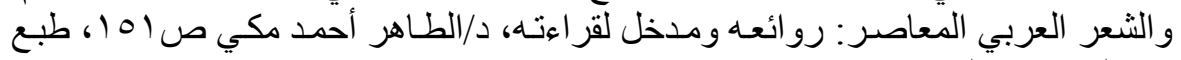


يتضح لنا مدى الطول الإيقاعي في النص.

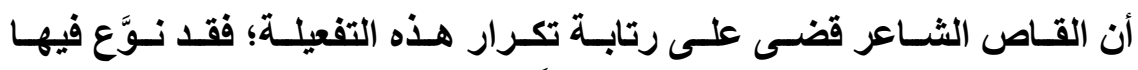
بين صورتين من الصور المقبولة عروضيَّا منها، هما:

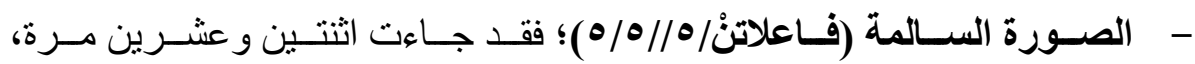

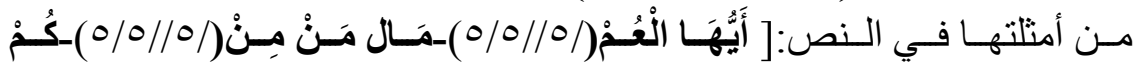

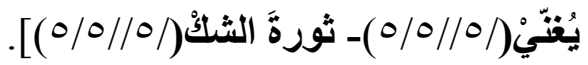

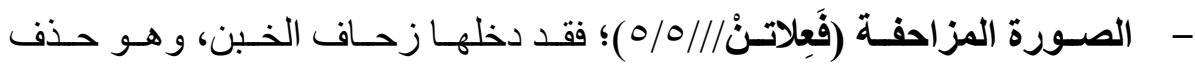

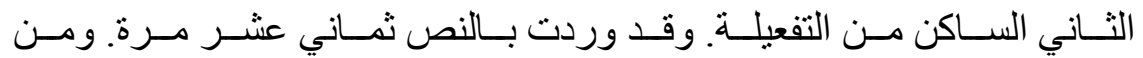

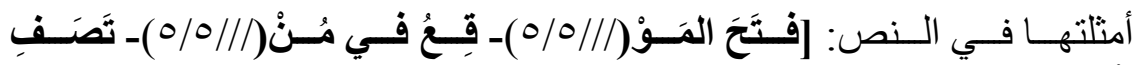

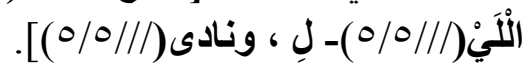

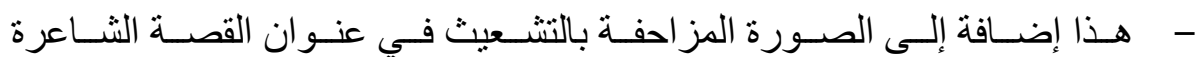
(تسريح فالاتن)).

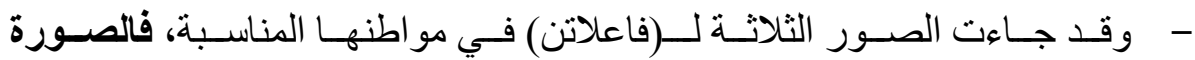

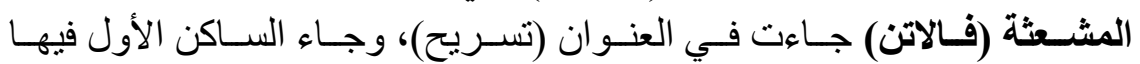

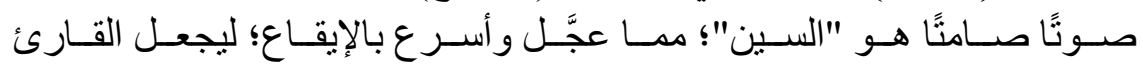

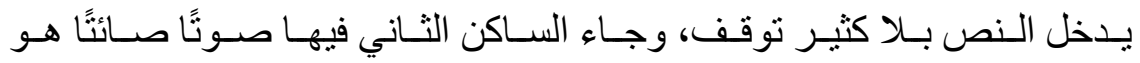

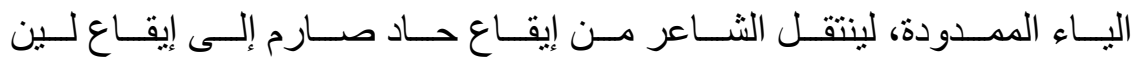

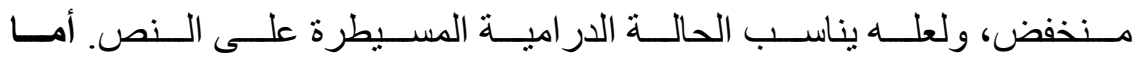

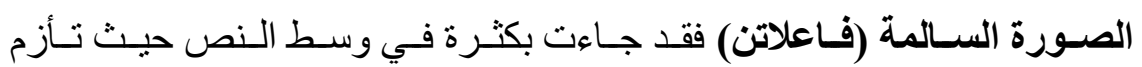

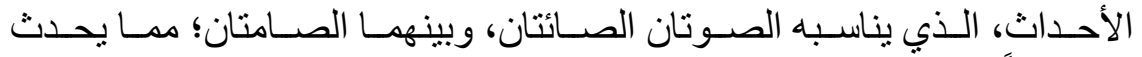

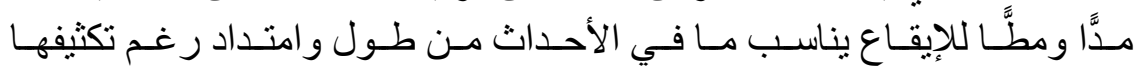

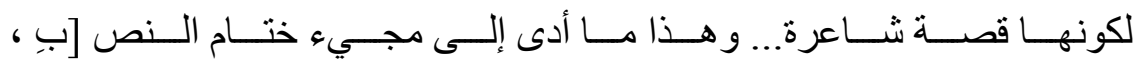

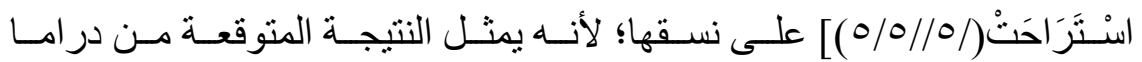

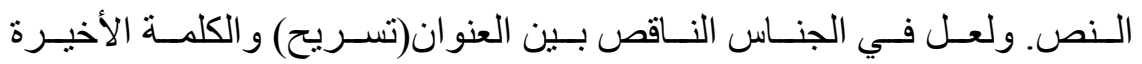

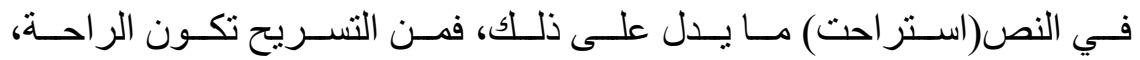

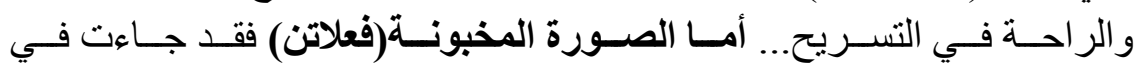

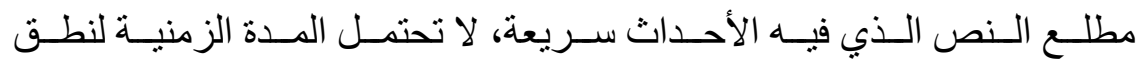




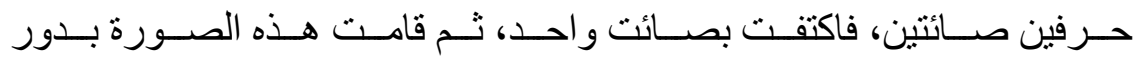

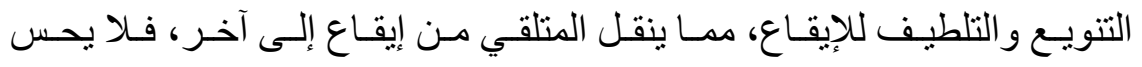
بثقل أو ملل من رتابة التفعيلة الواحدة.

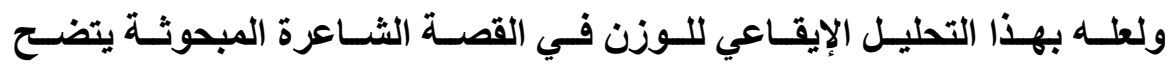

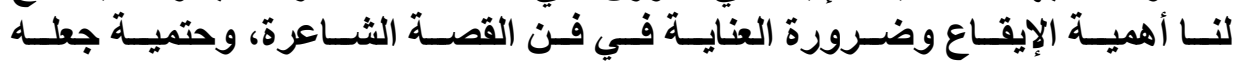

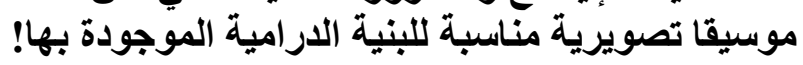

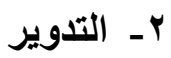

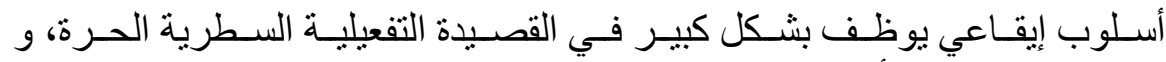

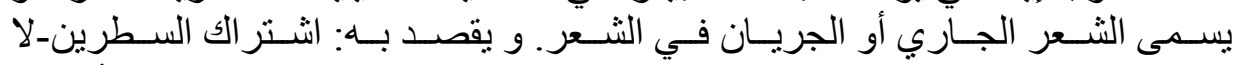

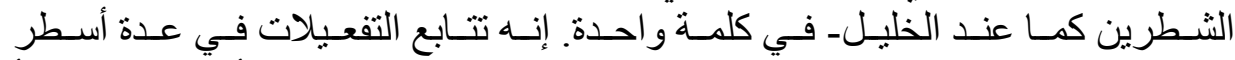

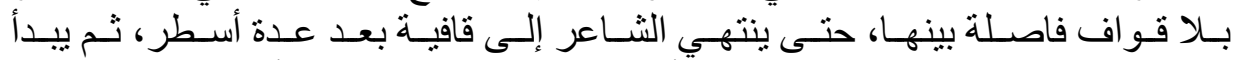

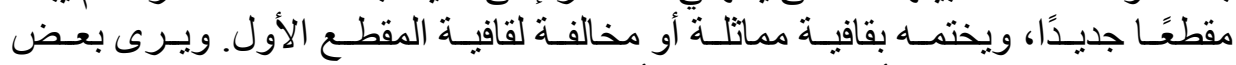

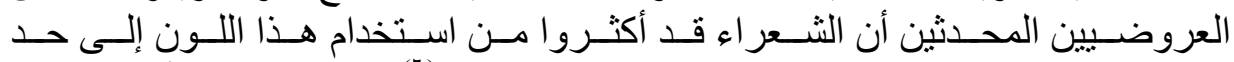

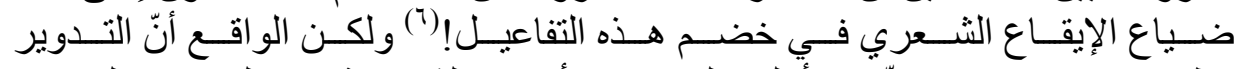

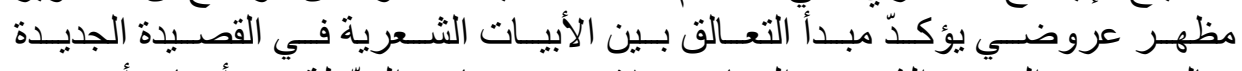

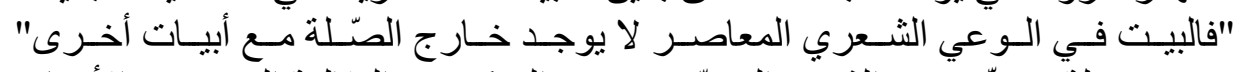

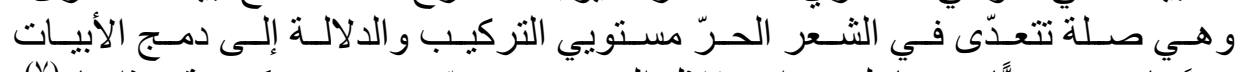

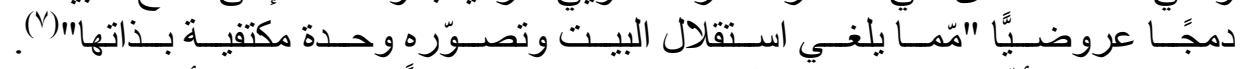

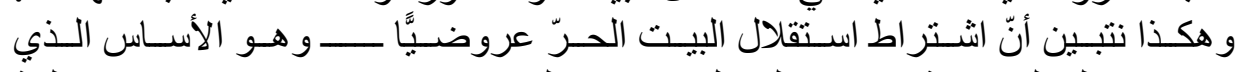

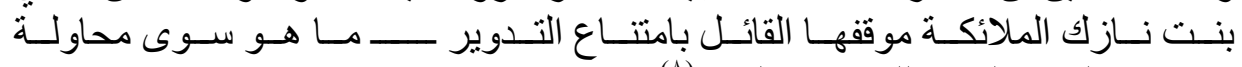

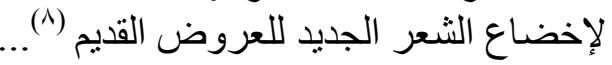

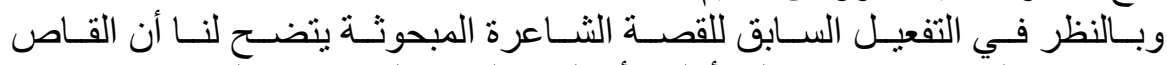

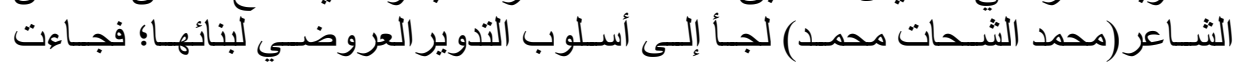

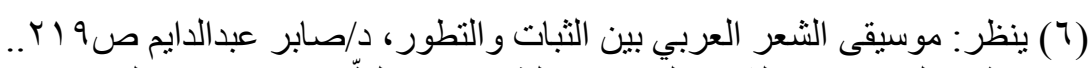

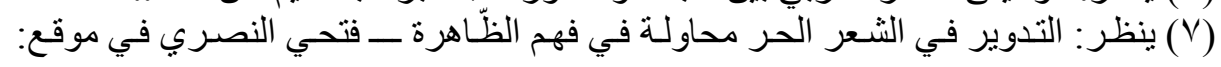
http://www.startimes.com ^ راجع في بيان هذا المصطلح كتابي (الصافي في العروض و القو افي) بالاشتر الك مـع الدكتور

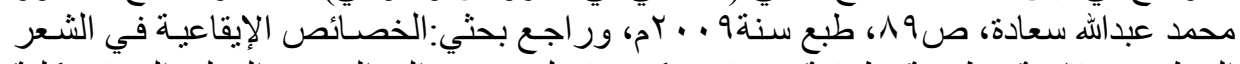

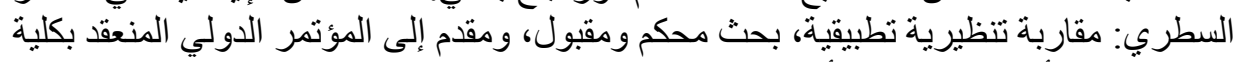

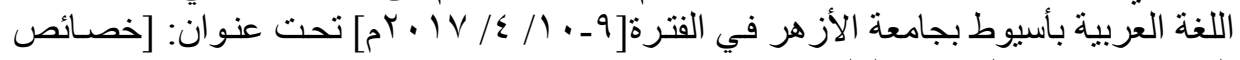




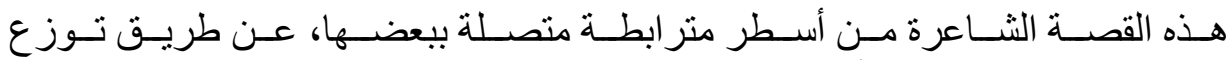

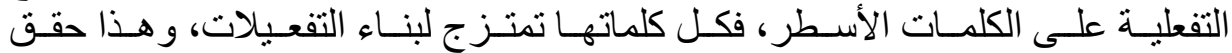

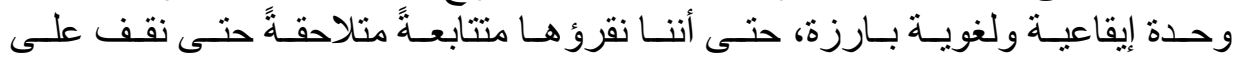

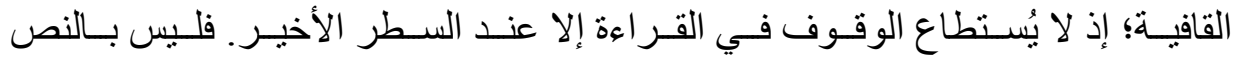

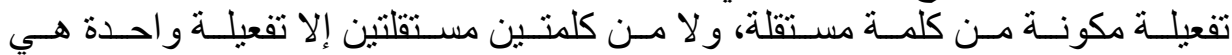

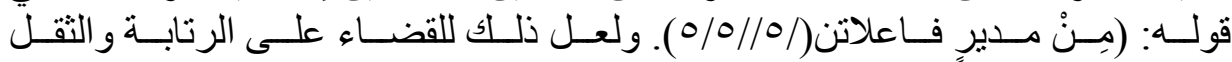

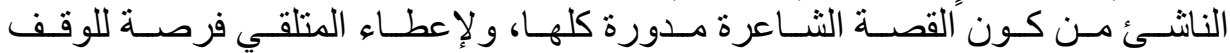

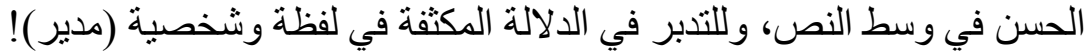

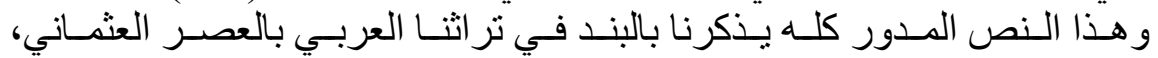

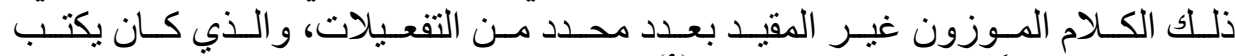

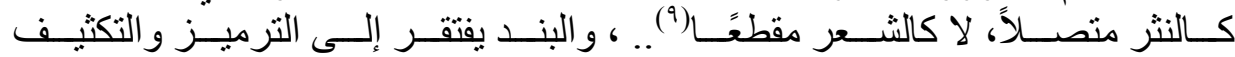
و غير هما كما في الثعر و القصة الثانة الثاعرة r- التضمين

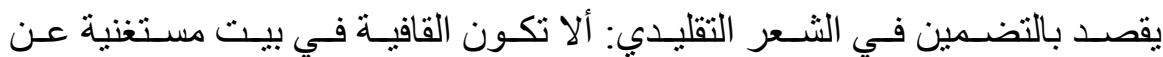

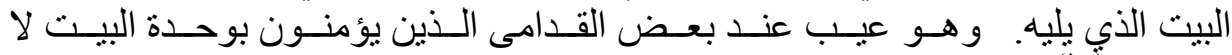

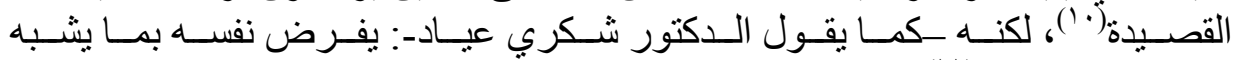

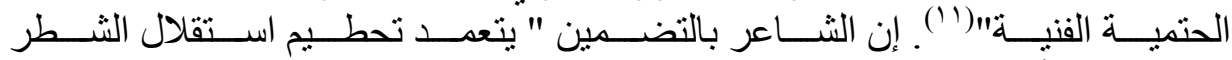

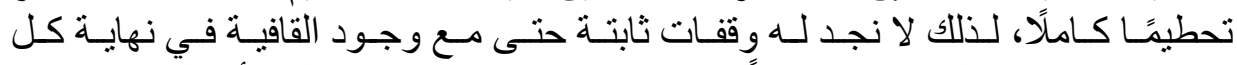

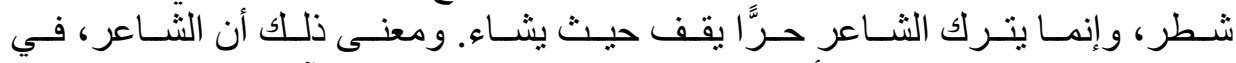

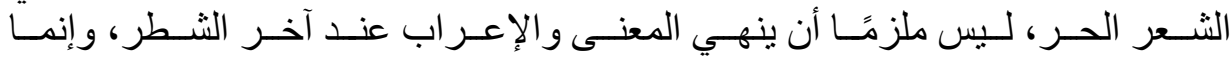

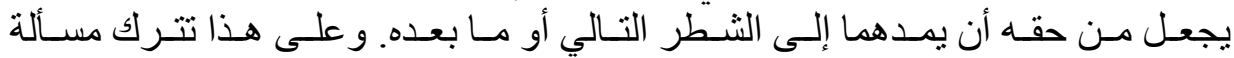

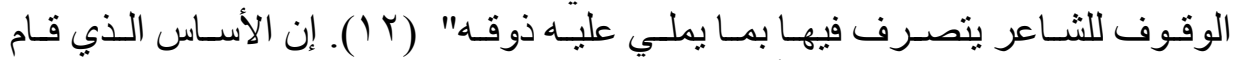

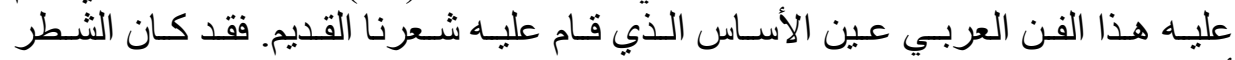

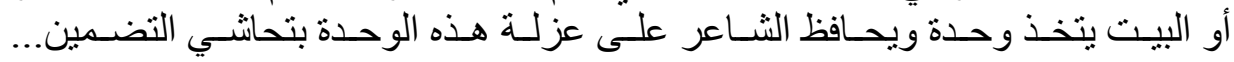

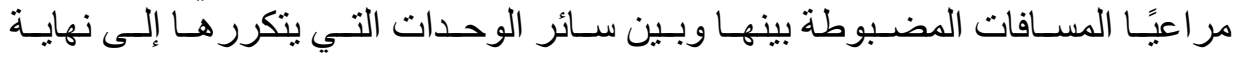

9 راجع في بيـان هذا المصطلح البند في الأدب العربي للدكتور عبدالكريم الجبيلي، طبع

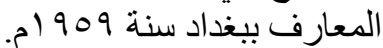

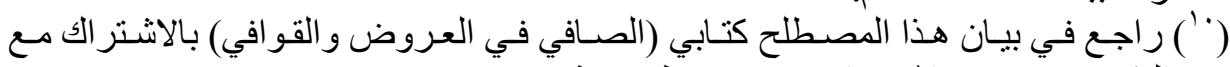

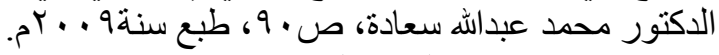

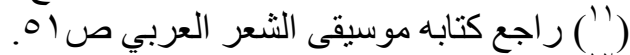

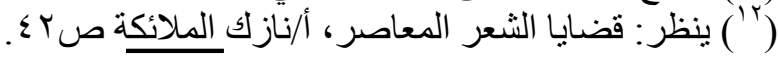




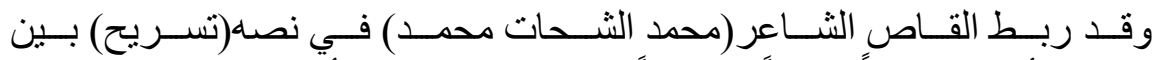

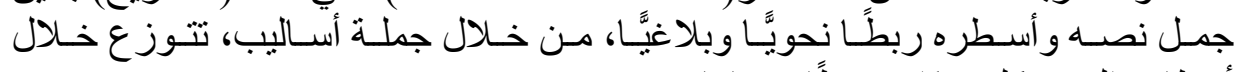

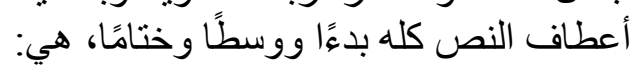

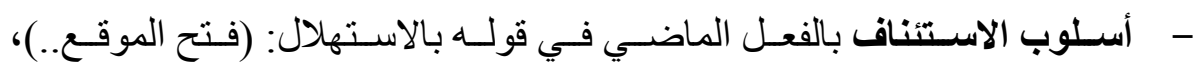

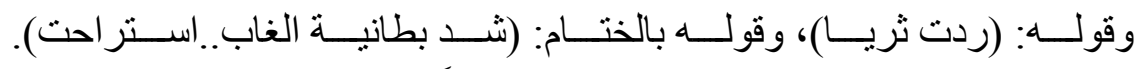

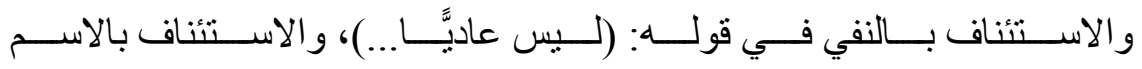

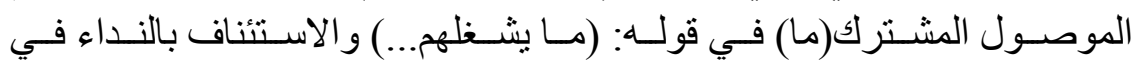

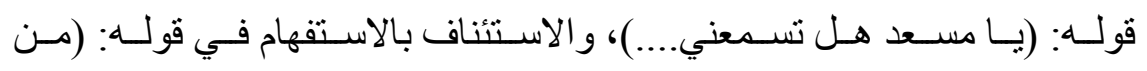

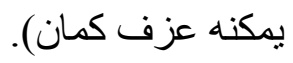

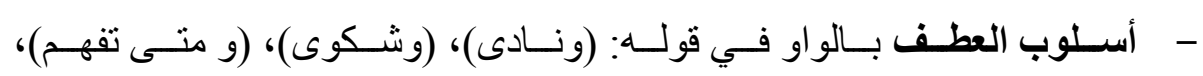
و العطف بـ (أو) في قوله: بـاله (أو لديه).

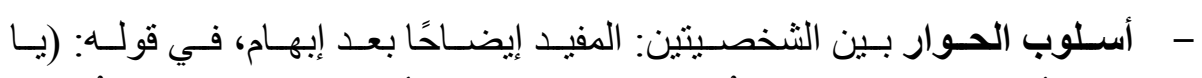

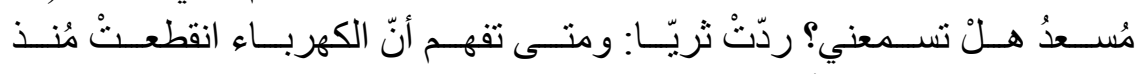
خروج الليثث في نشرة أصحاب المعالي؟).

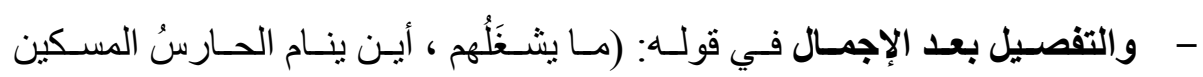

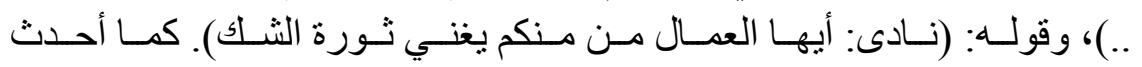

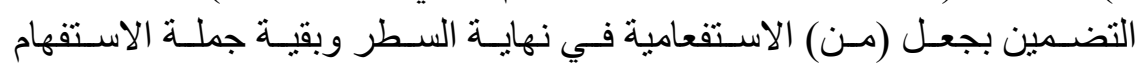

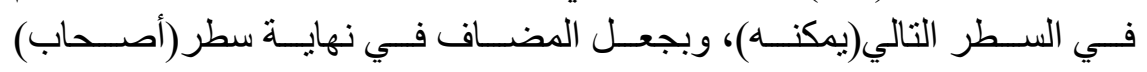
و والمضاف إليه في بداية سطر نالئل (المعالي).

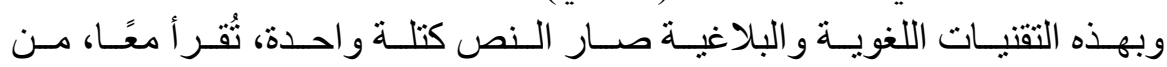

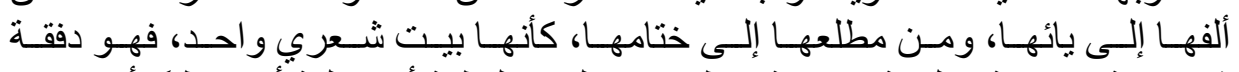

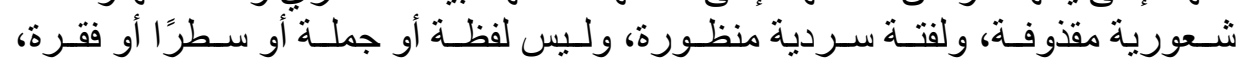

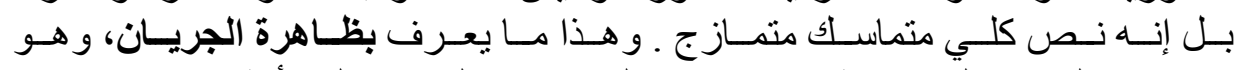

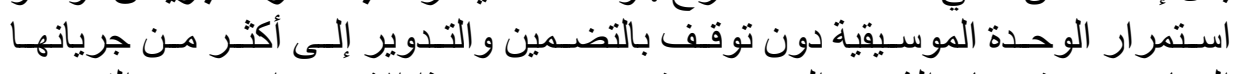

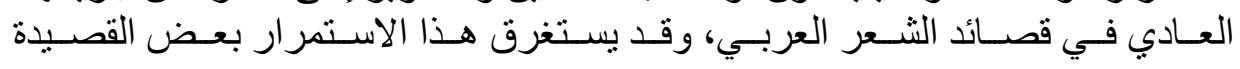




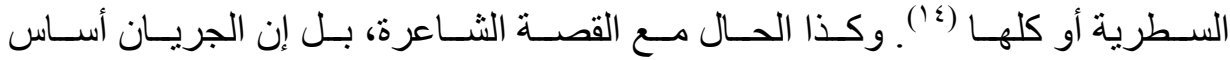
إيقاعي فيها. ع- التقفية

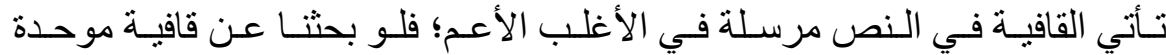

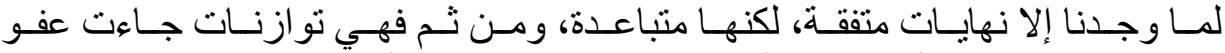

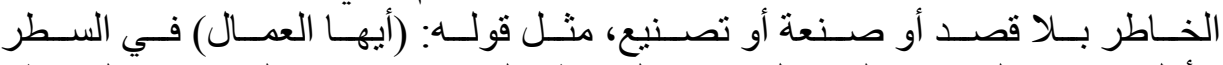

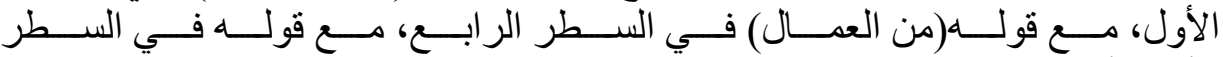

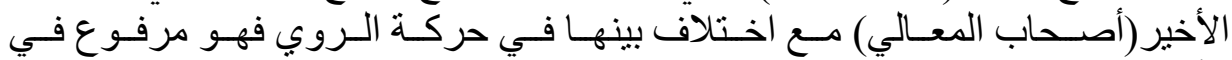

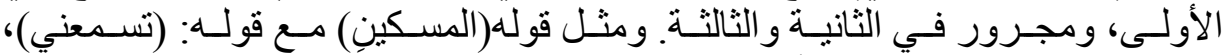

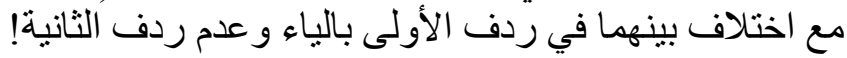

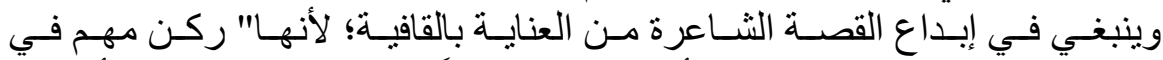

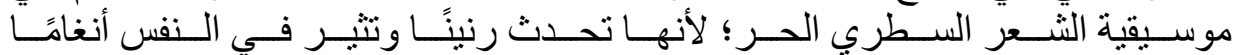

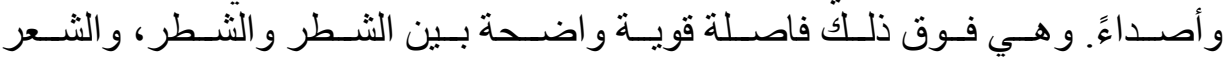

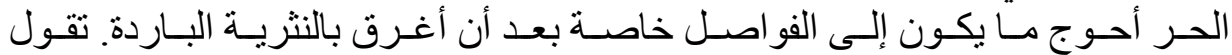

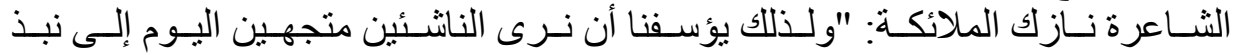

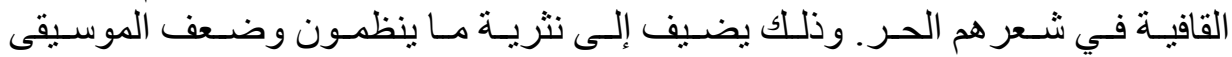

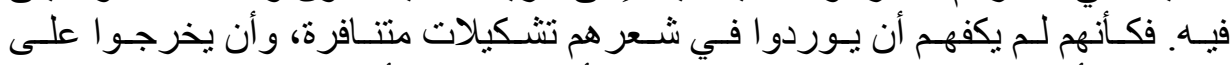

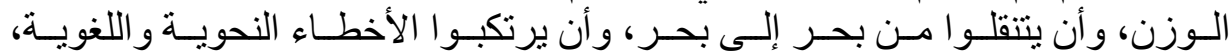

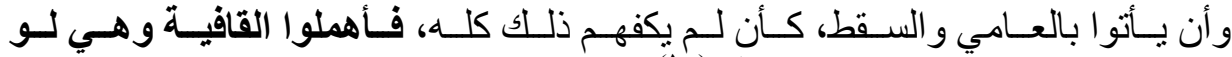

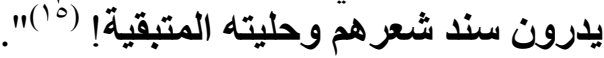

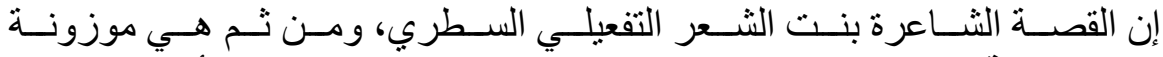

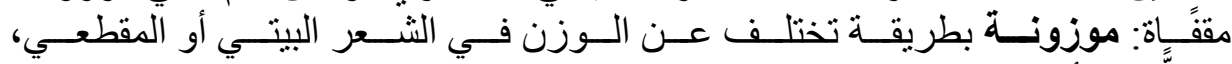

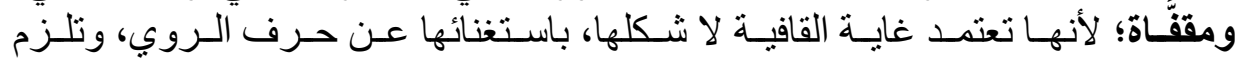

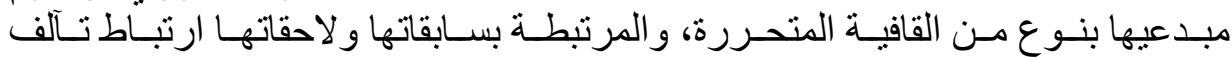

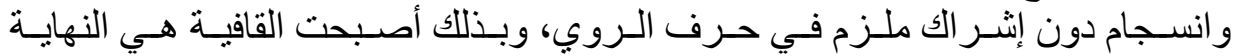

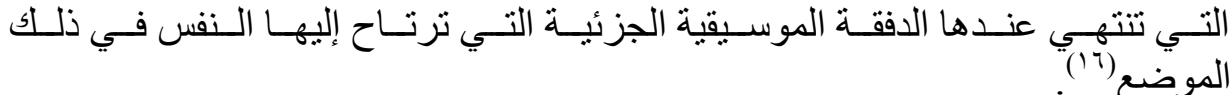

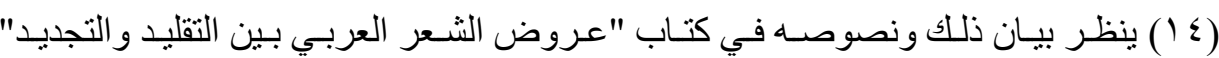

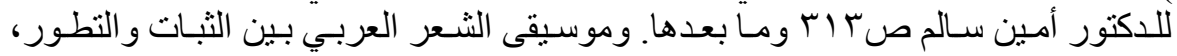

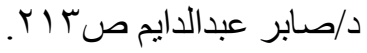

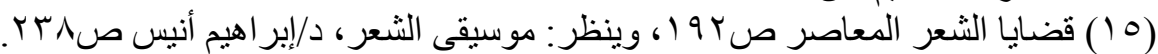

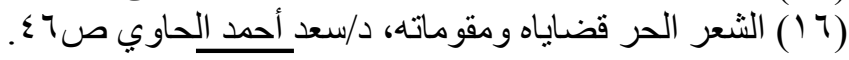




\section{الإيقاع البصري في القصة الثناعرة}

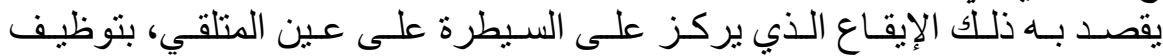

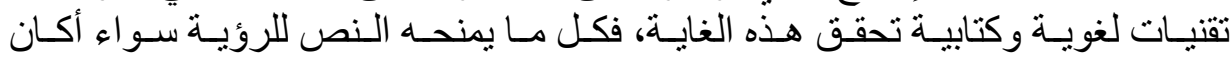

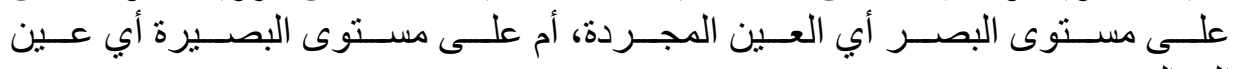

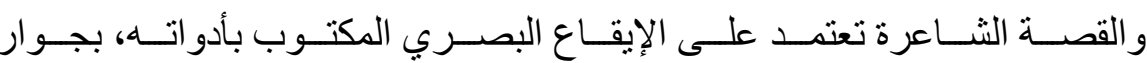

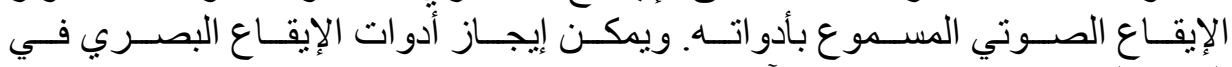
القصة الثناعرة: (تسريح)، في الآتي: الإنيك

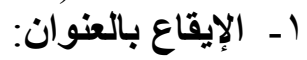

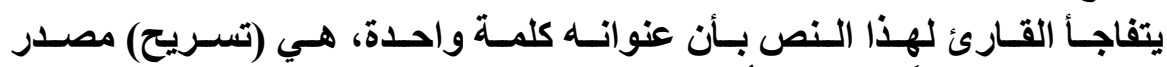

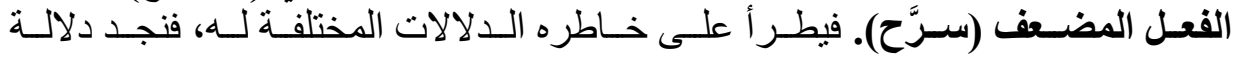

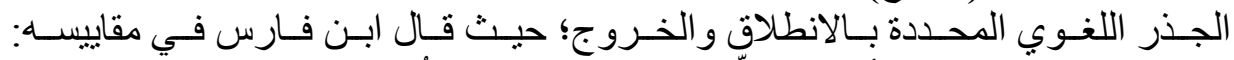

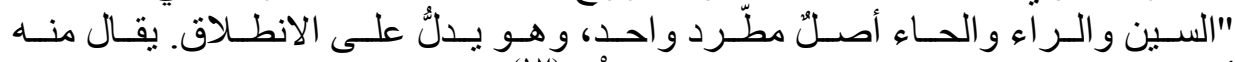

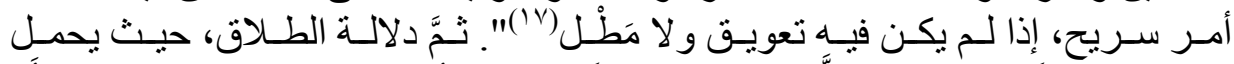

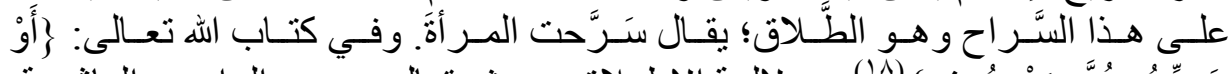

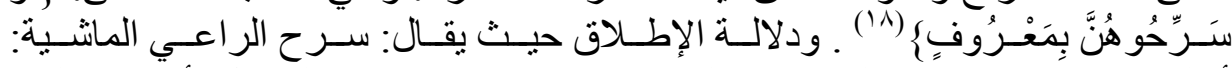

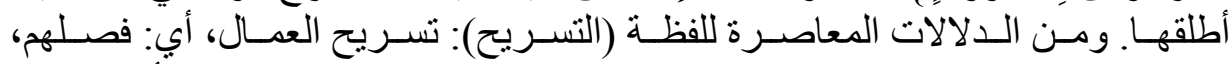

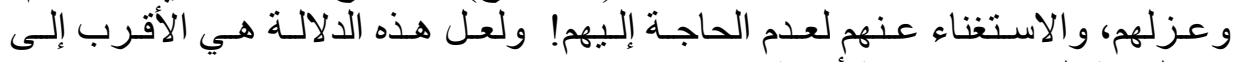

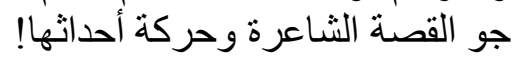

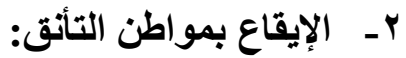

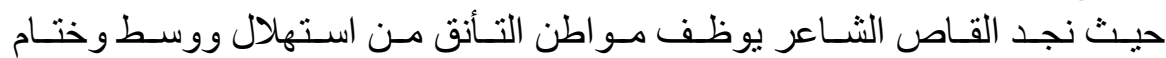

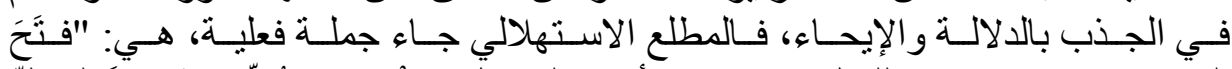

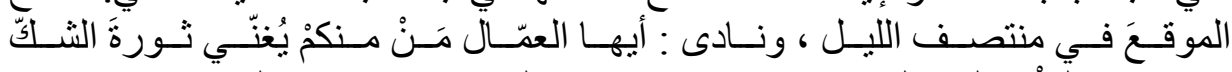

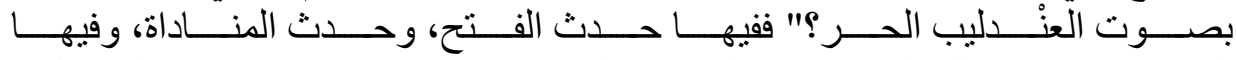

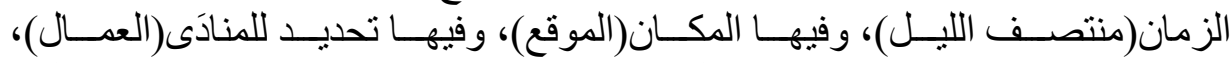

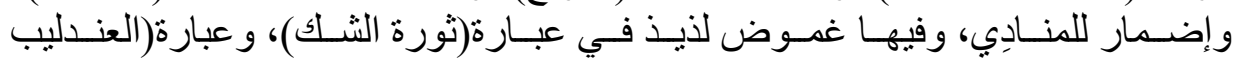

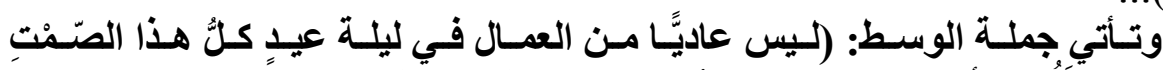

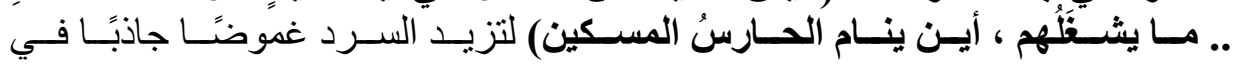

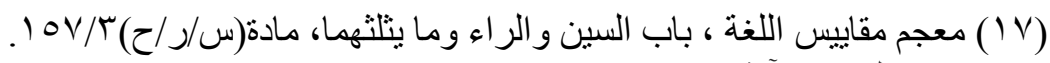
IV

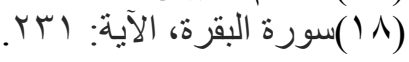




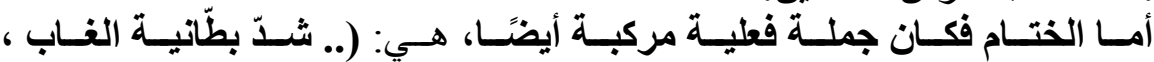

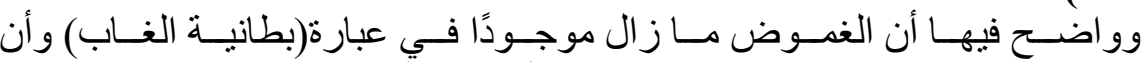
(ستر احتُ ).

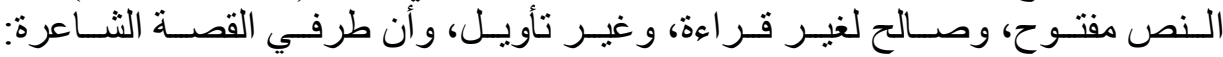

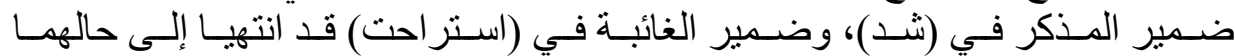

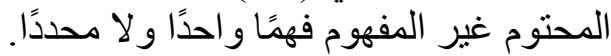

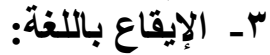

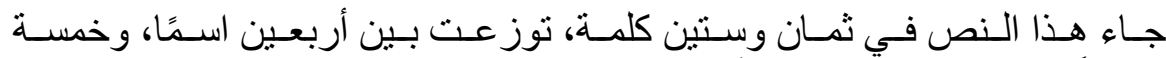

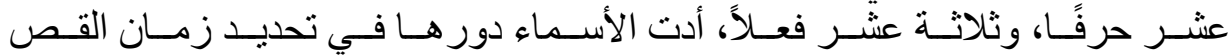

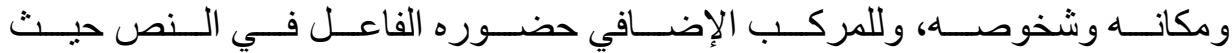

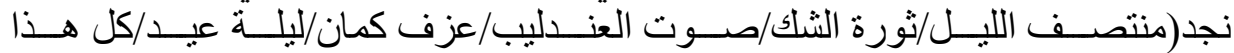

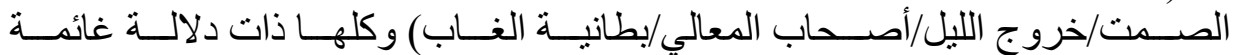

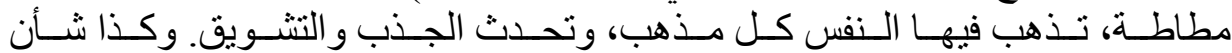

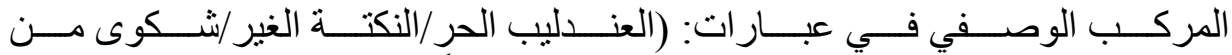

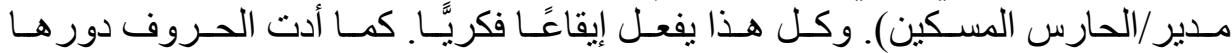

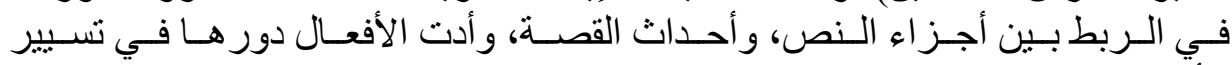

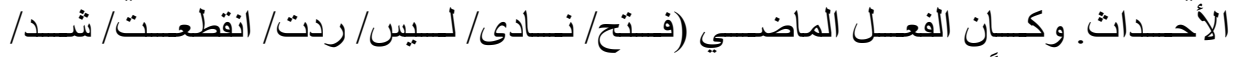

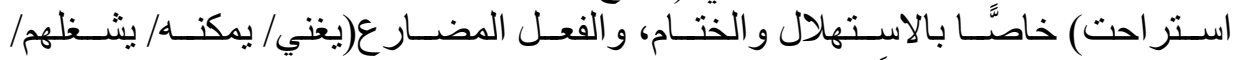

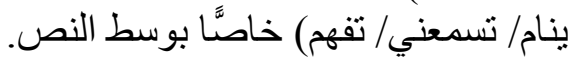

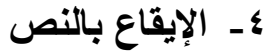

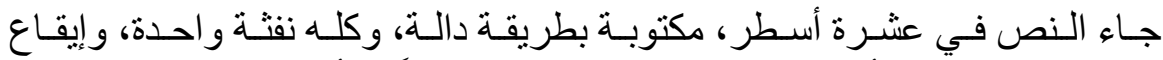

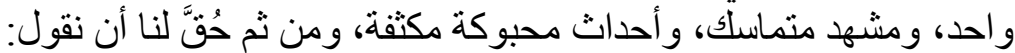

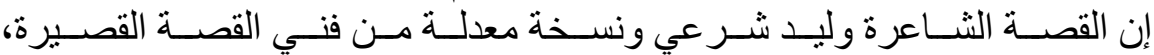

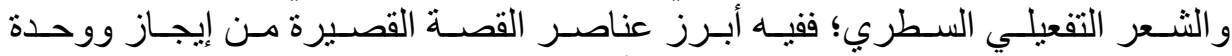

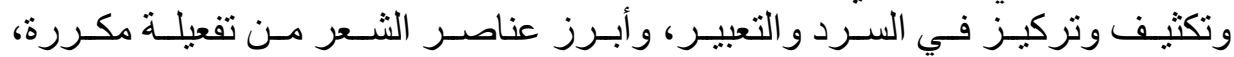

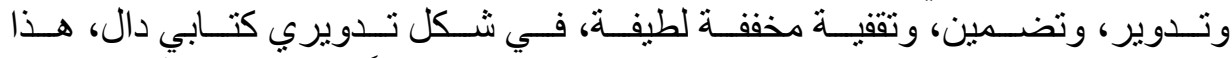

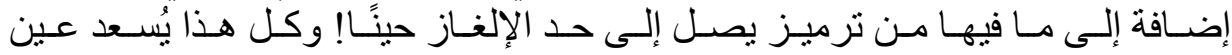

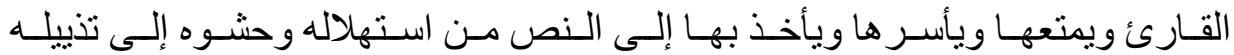

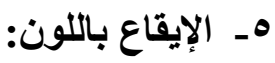

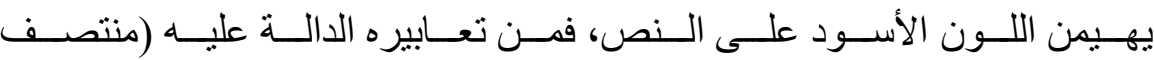




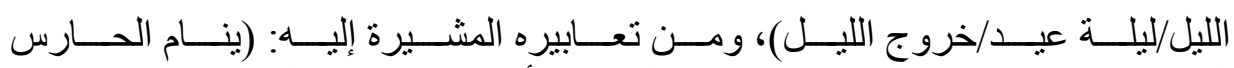

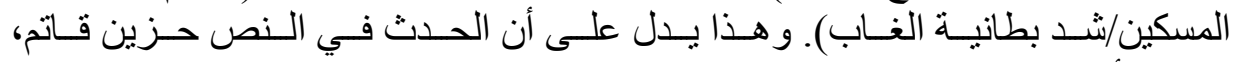

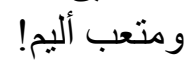

צ- الإيقاع بعلامات الترقيم:

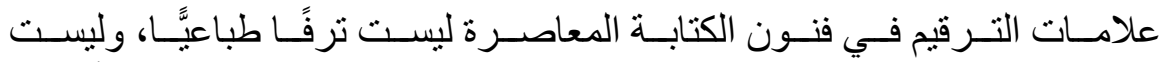

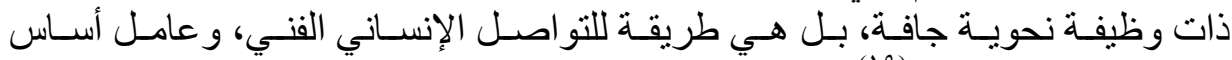

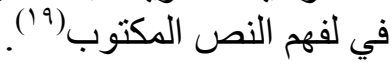

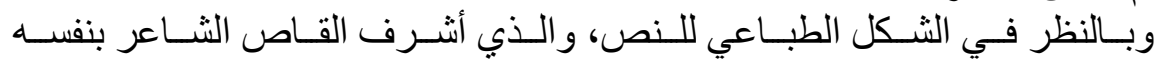

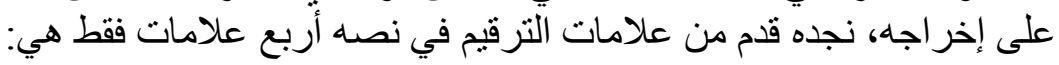

- - الفاصلة

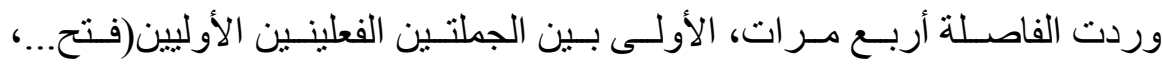

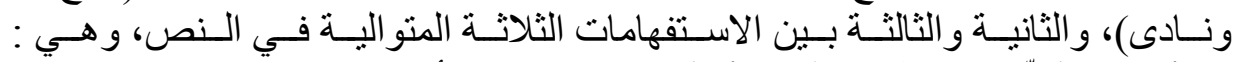

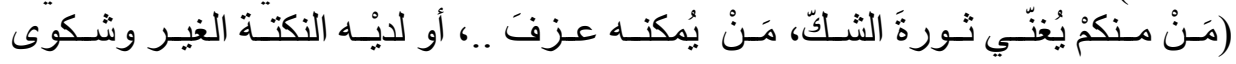

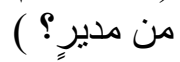

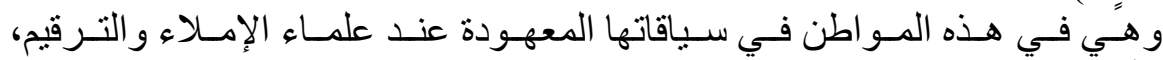

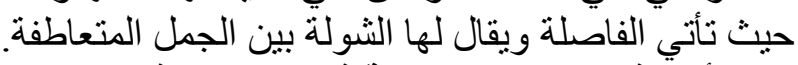

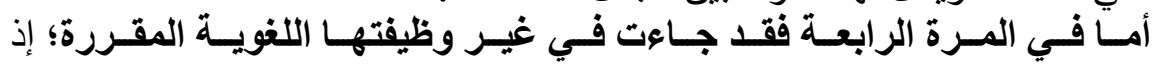

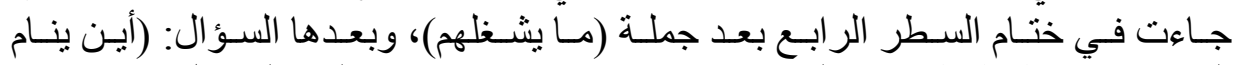

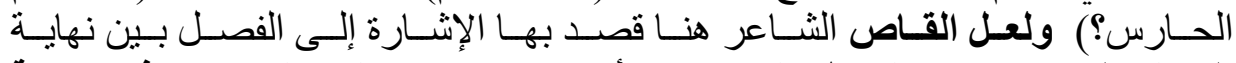

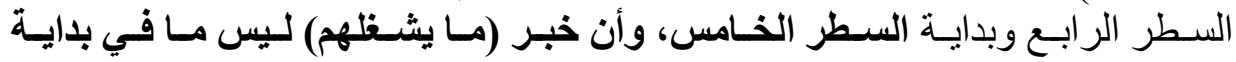

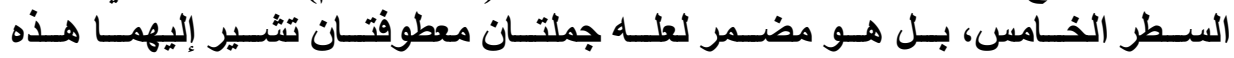
الفاصلة الخاتمة للسطر.

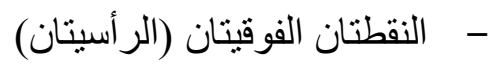

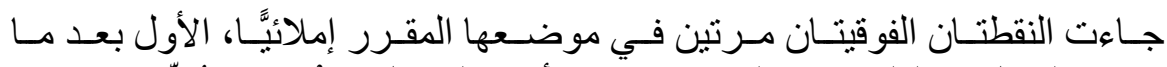

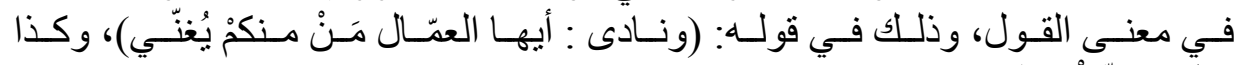
قولَه: (ردّتثْ ثريّا: ومنى تفهم).

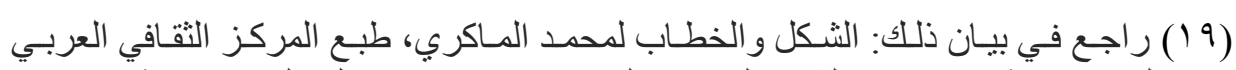

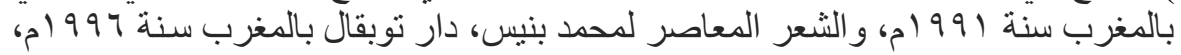

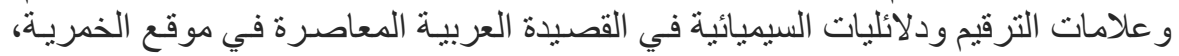

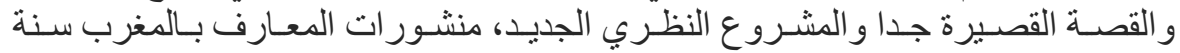


- علامة الاستفهام

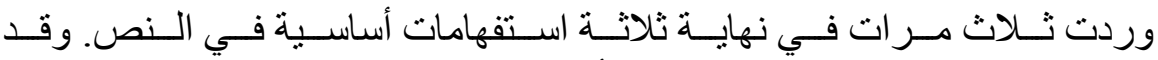

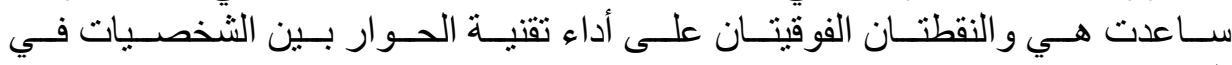

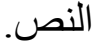

- - - النقتان الأفقيتان

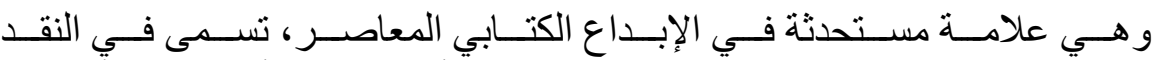

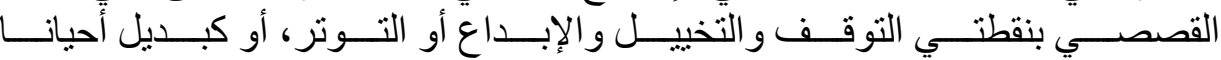

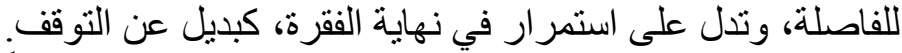

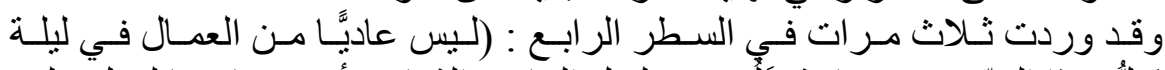

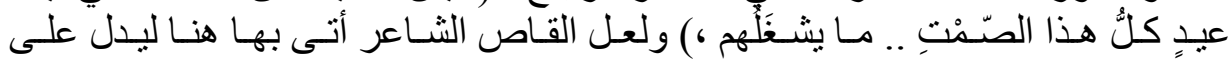

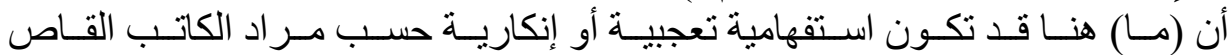

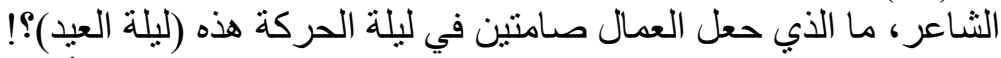

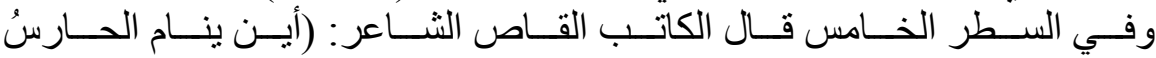

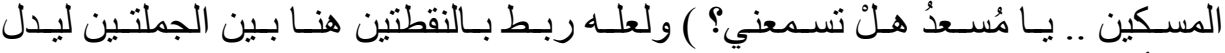

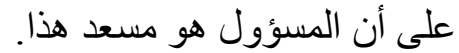

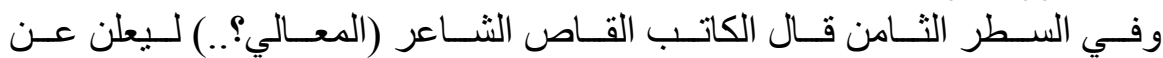

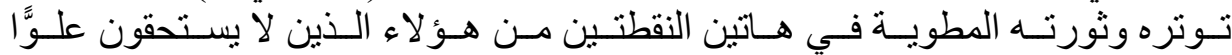
و ولا ارتفاعًا!

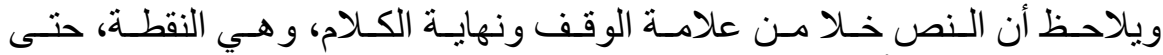

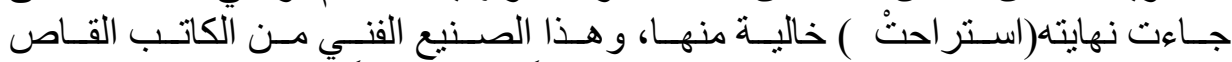

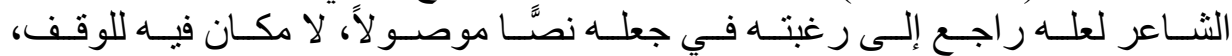

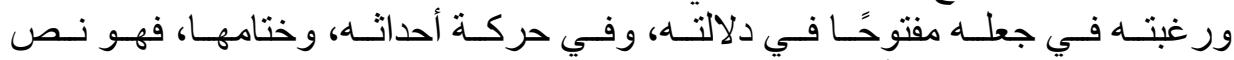

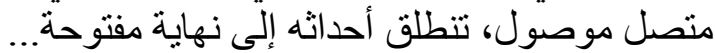

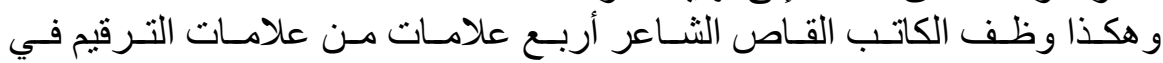

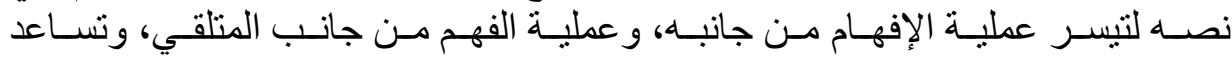

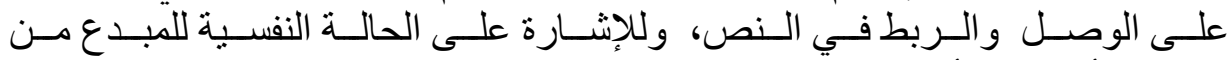

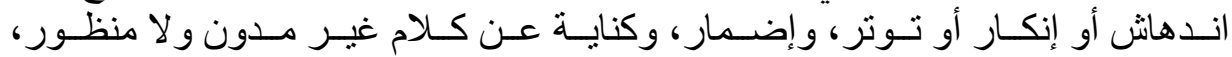

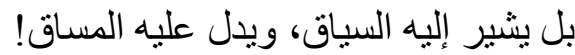

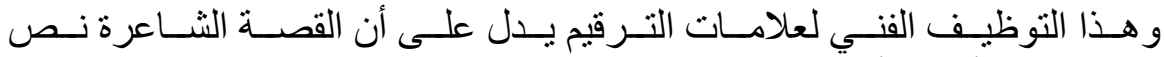

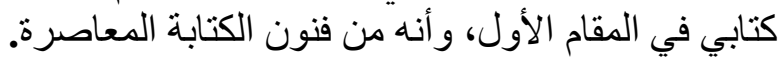

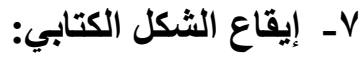

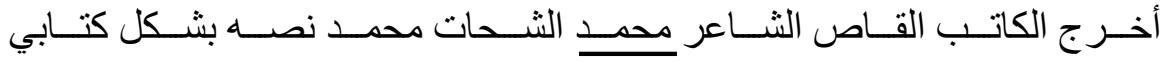
$r$. 


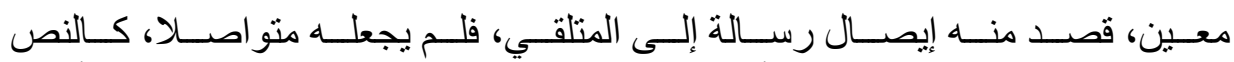

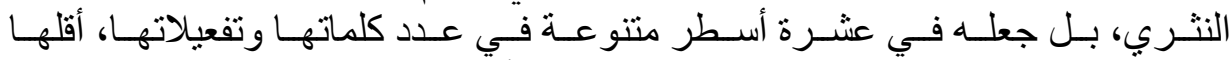

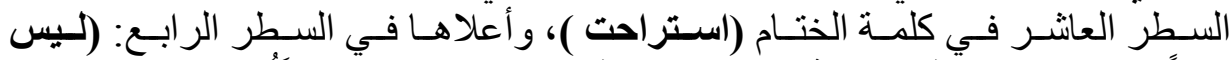

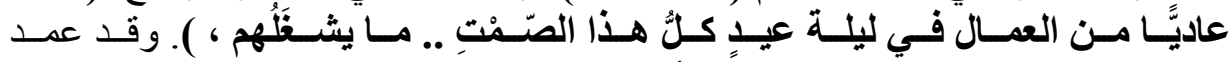

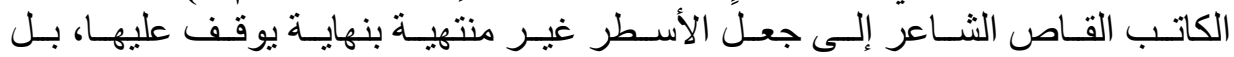

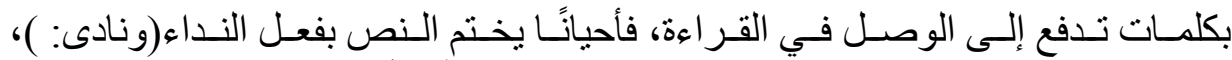

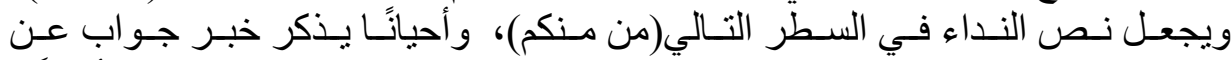

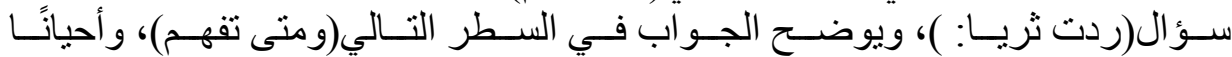

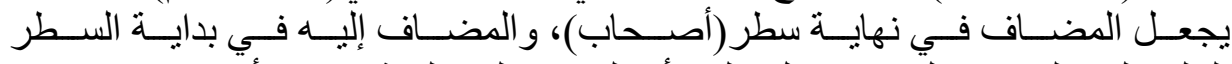

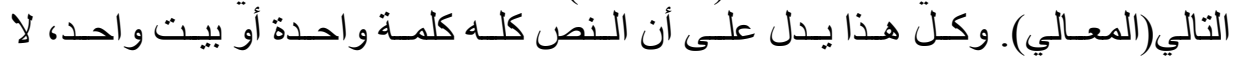

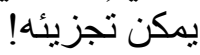

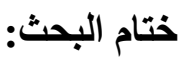

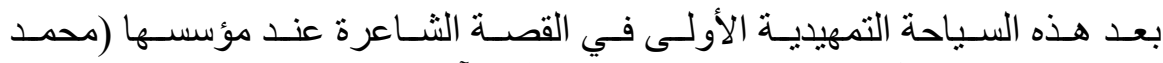

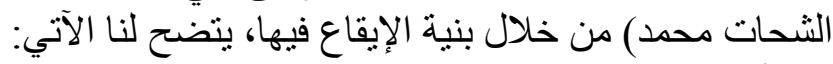

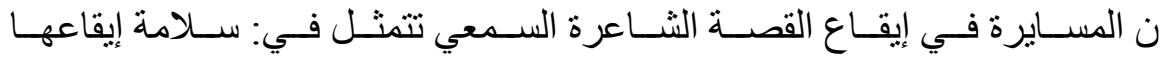

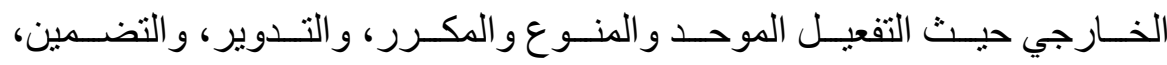
و التقفية المرسلة المنداعية.

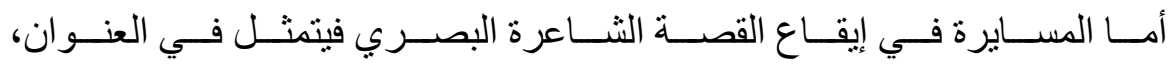

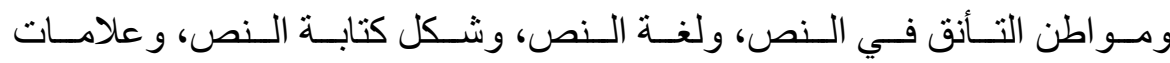

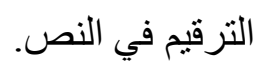

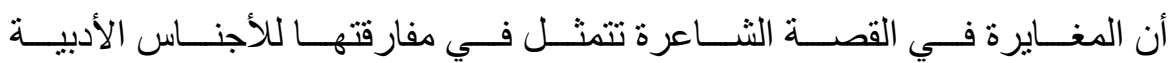

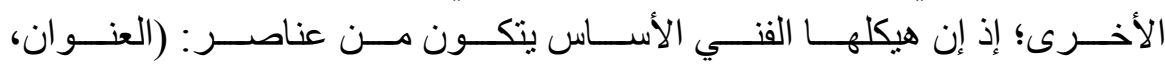

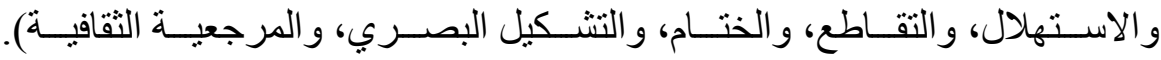

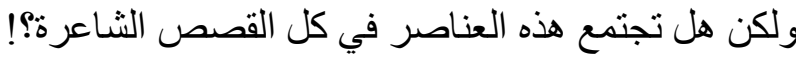
إن القصة الثاعرة المثال هي التي تجمع بين هذه النئ البنى الأساسية.

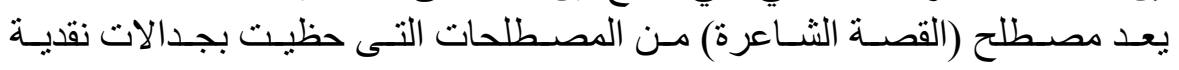

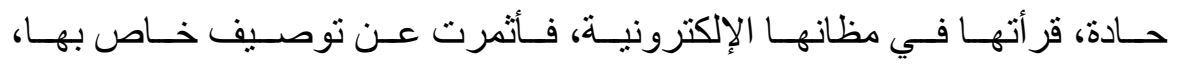

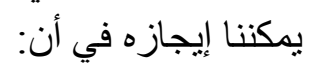

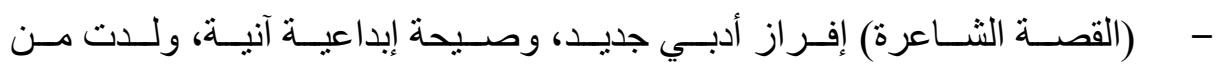
T) 


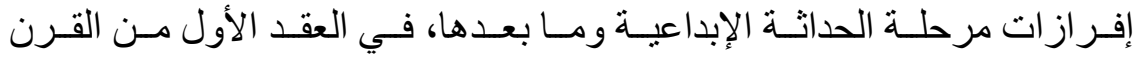

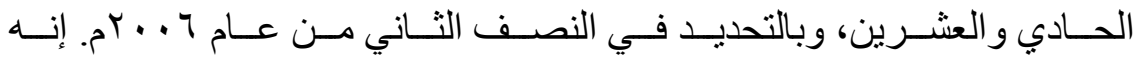

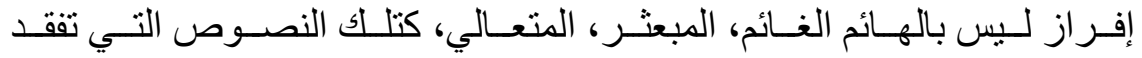

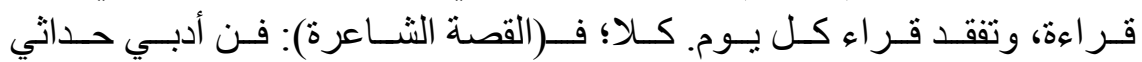

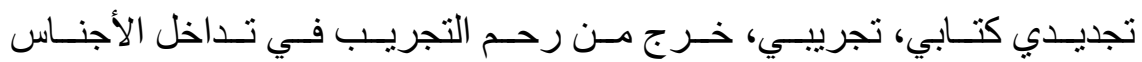

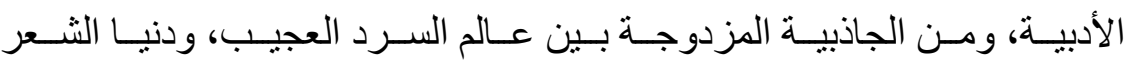

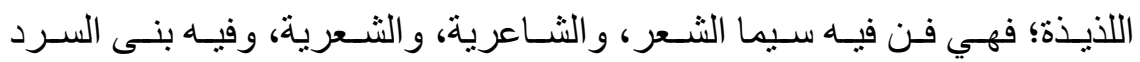

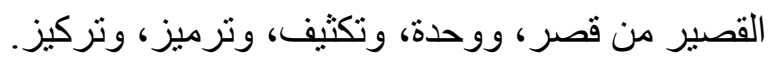

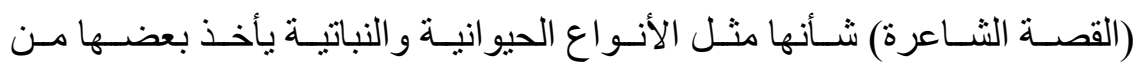

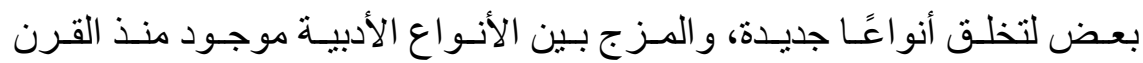

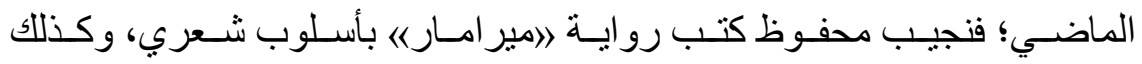

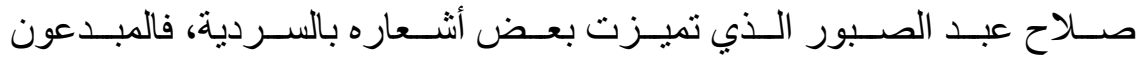

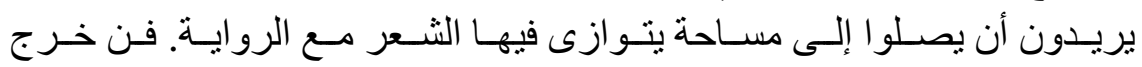

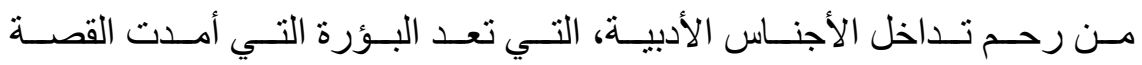

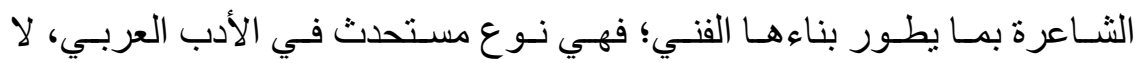

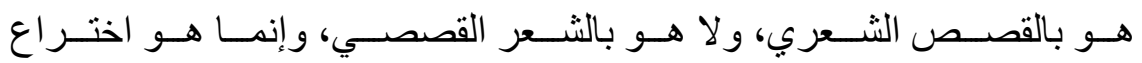

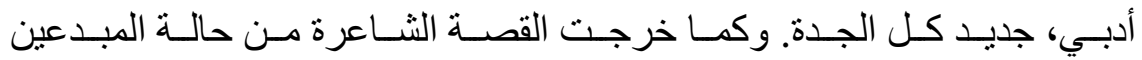

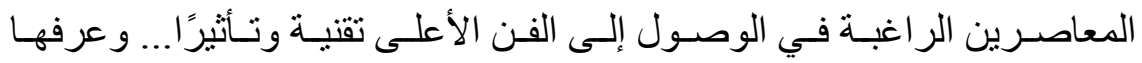

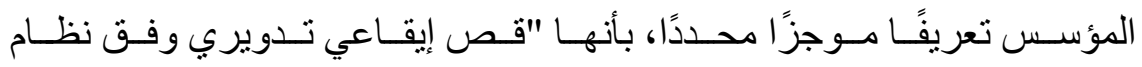
التفعيلة، مؤسسة على التكثيف و الرمز و المرجعيات التقافية".

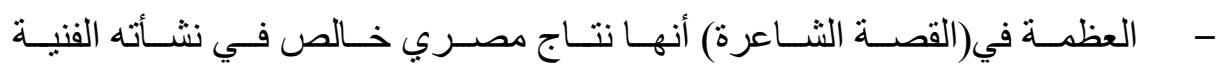

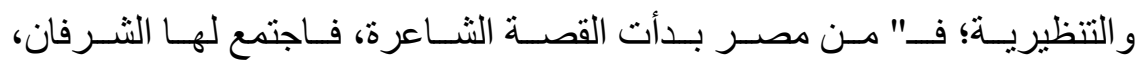

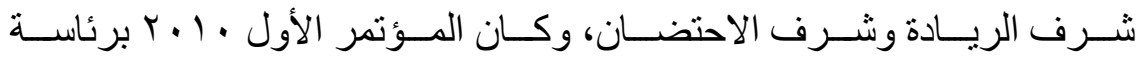

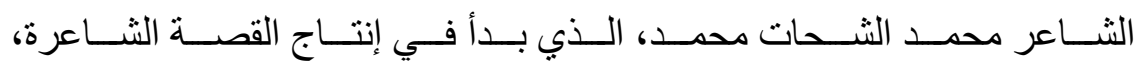

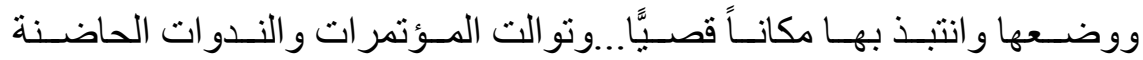

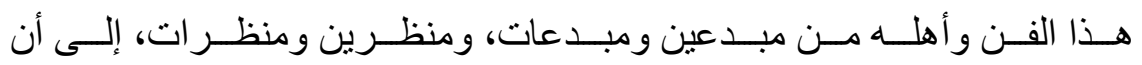

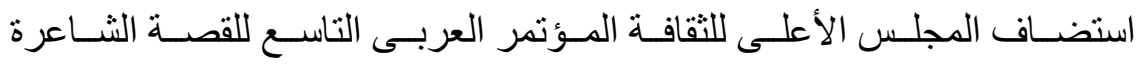

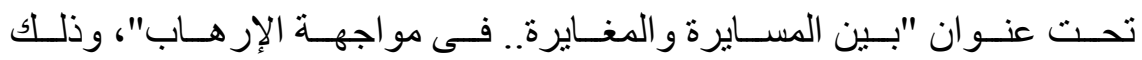




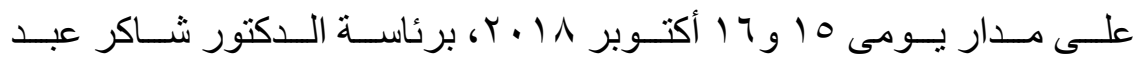

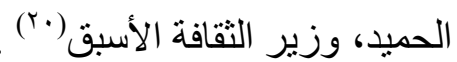

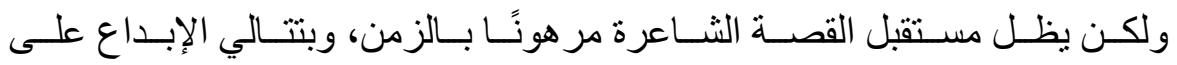

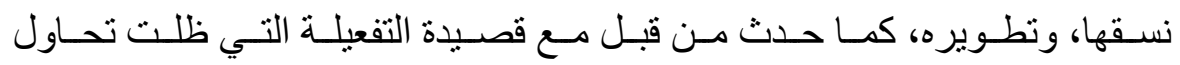

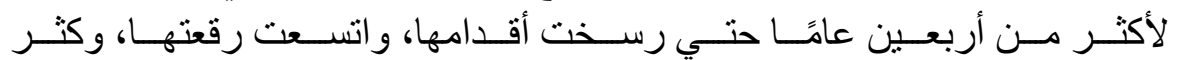

$$
\text { المبدعون بها وفيها. }
$$

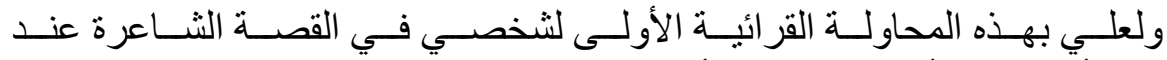

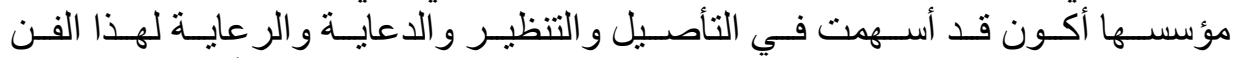

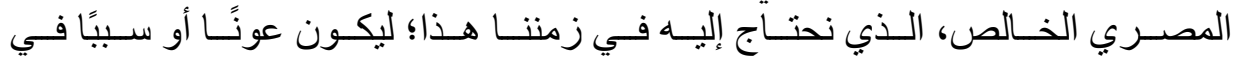

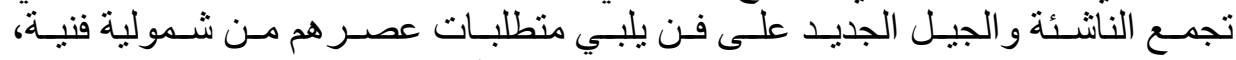

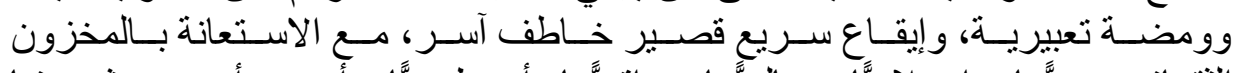

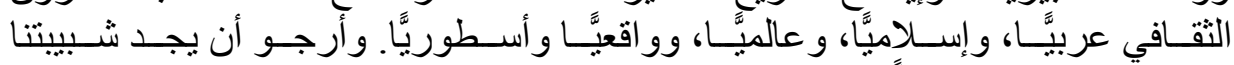

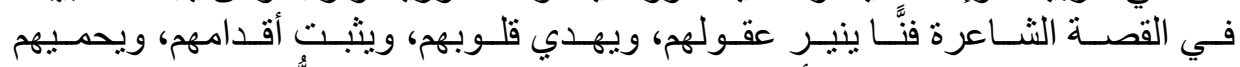

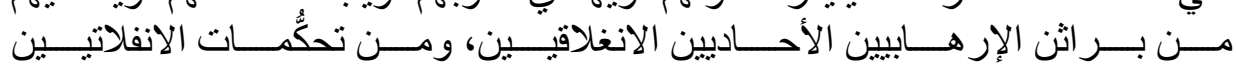

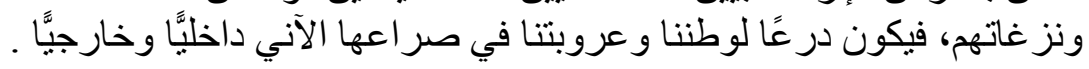

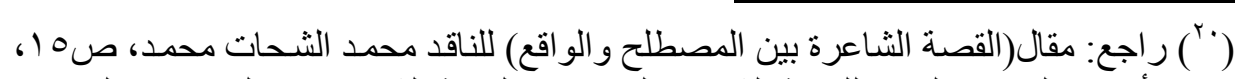

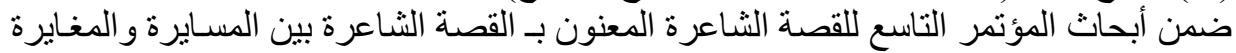

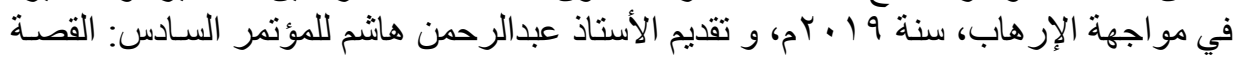

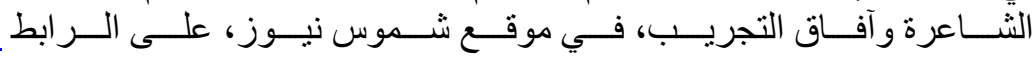

\section{http://www.shomosnews.com}




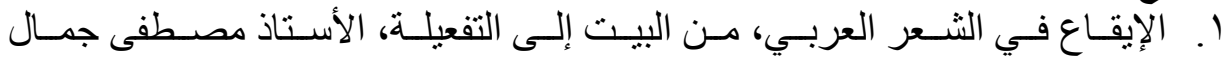

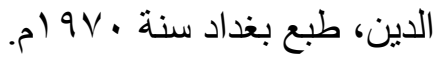

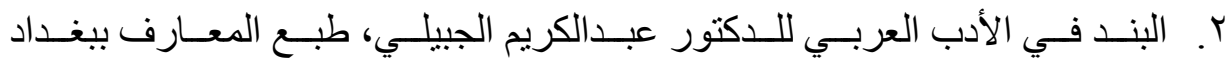
سنة 909 (م.

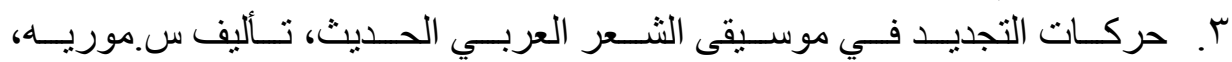

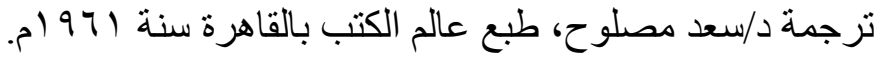

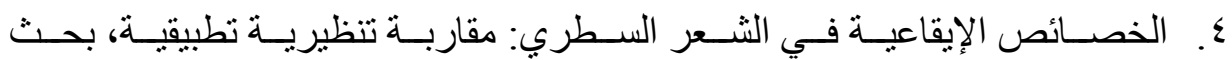

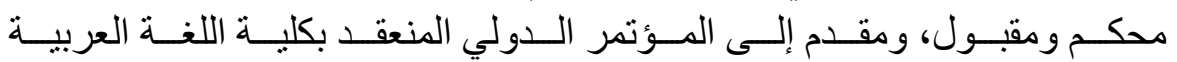

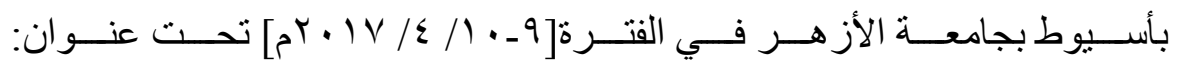
[خصائص العربية في ضوء التاريخ و العلم].

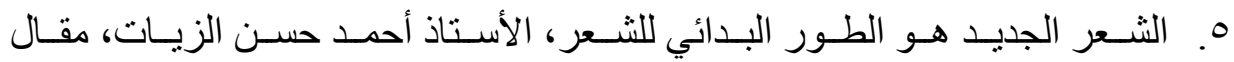

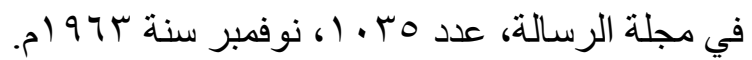

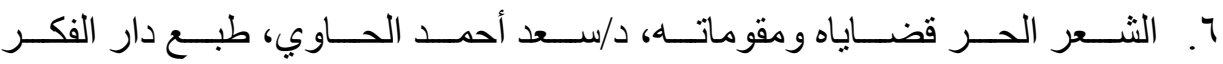

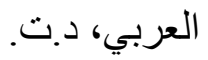

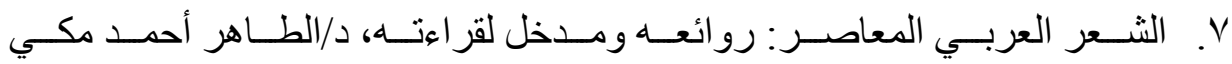

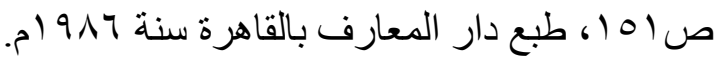

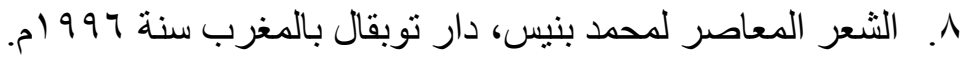

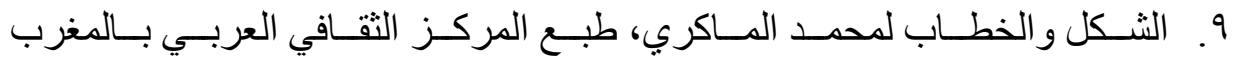

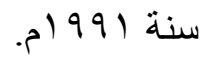

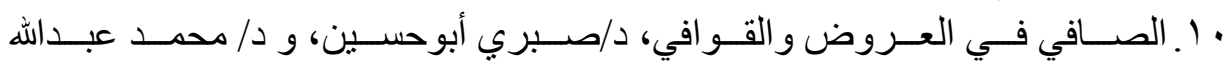

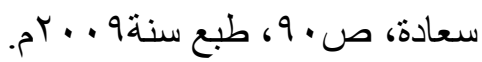

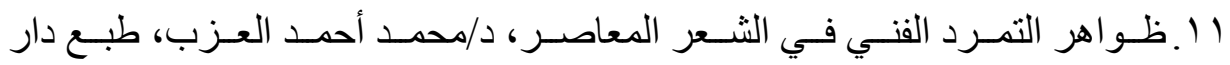

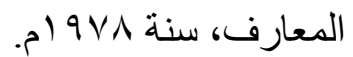

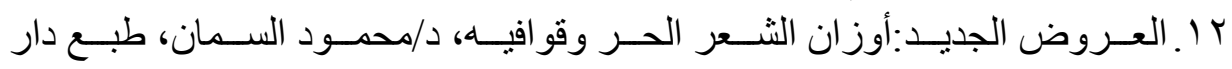

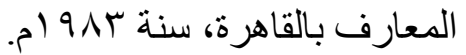

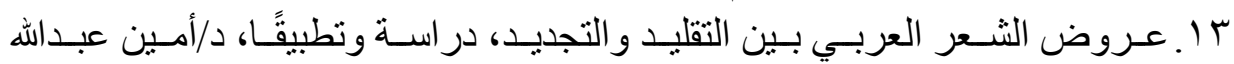

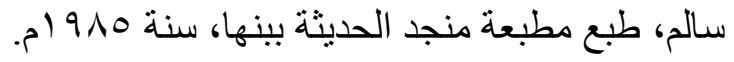




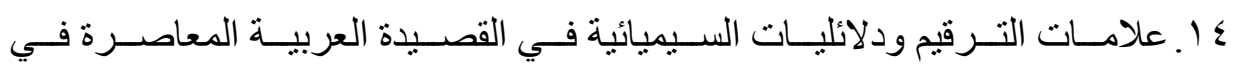

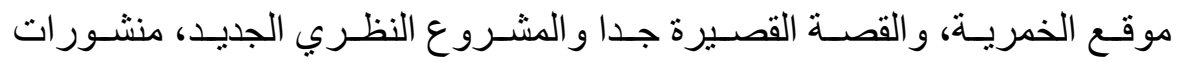

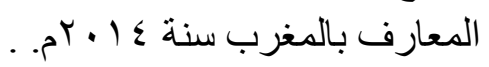

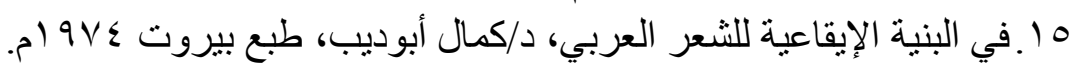

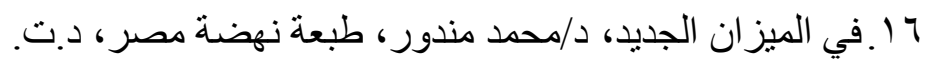

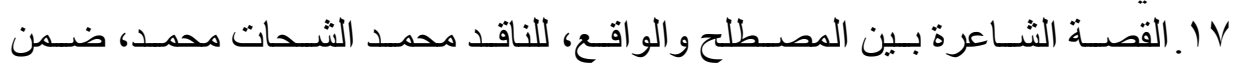

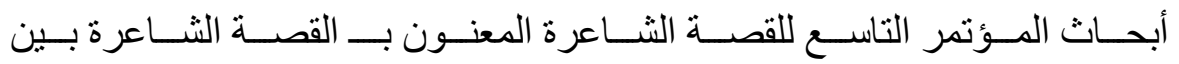

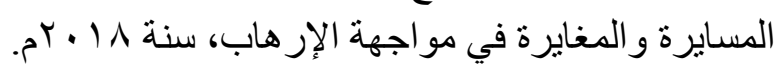

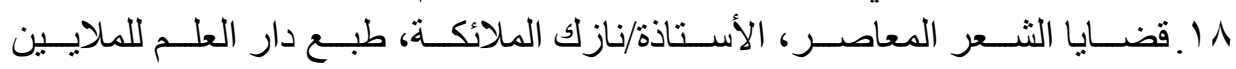

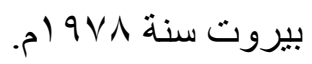

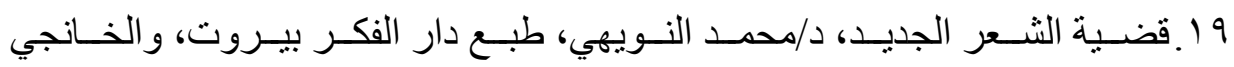

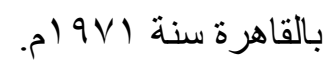

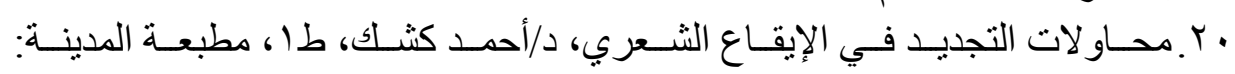

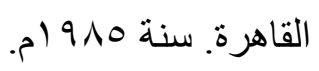

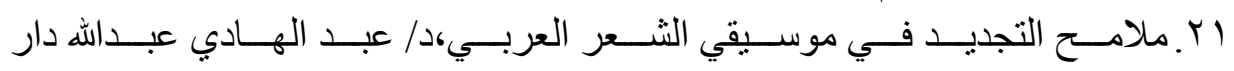
المعرفة الجامعية: الإسكندرية. سنة ، 99 (م.

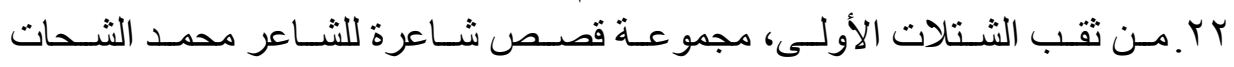

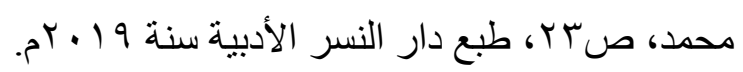

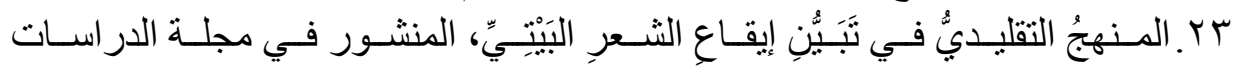

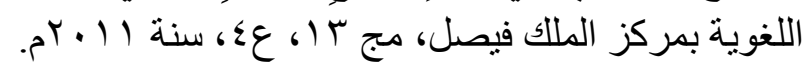

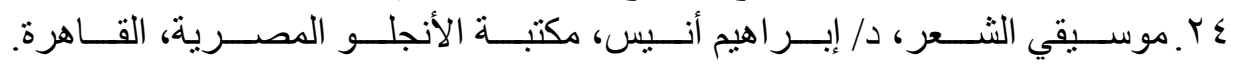

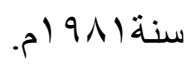
هץ.موسيقى الشعر العربي، د/شكري عياد، طبع القاهرة سنة 1979 ام.

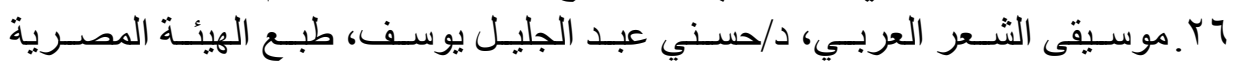

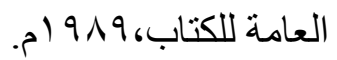

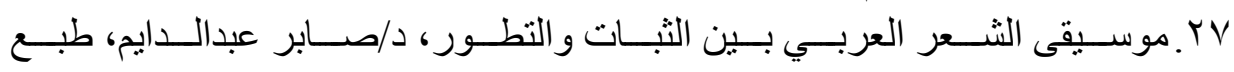

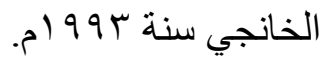

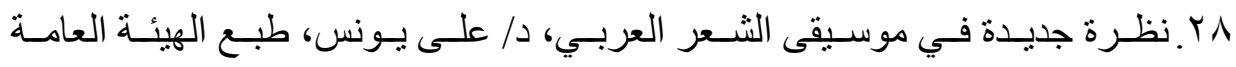


للكتاب سنة ب99 (م. 